\title{
Integrated analytical approach to unveil the secrets of the recently discovered "Sphinx Room": a new piece of Domus Aurea puzzle
}

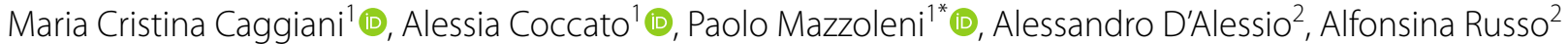 \\ and Germana Barone ${ }^{1}$ (1)
}

\begin{abstract}
The recent discovery of the Sphinx Room, belonging to the Domus Aurea Esquiline wing, thanks to the framework given by the project "Non-destructive analytical studies at Parco Archeologico del Colosseo (Rome, Italy)", allowed to perform an analytical campaign, both in situ and on micro-fragments. The first aim was to contribute to the overall comprehension of the Domus Aurea complex and to contextualize the newly-discovered room inside this extraordinary imperial architecture by means of an archaeometrical characterisation of the painting materials. The palette, composed of Egyptian blue, green earths, iron- and lead-based red, orange and yellow, calcite, carbon-based black, allowed to compare the Sphinx Room to Corridor 92 and Room 114 of Domus Aurea and to other sites in Rome. Furthermore, the employ of an organic binder in some spots can be put forward based on spectroscopic results, which does not exclude a wider use of the a fresco. Furthermore, a complementary methodological strategy was designed, in order to achieve a complete characterization of the materials. In addition to the well-known combination of portable X-ray fluorescence and portable/laboratory Raman analyses, Infrared Fourier Transform Spectroscopy was used, both in situ (Diffuse Reflectance) and in the lab (Attenuated Total Reflectance). The results confirm the suitability of this approach for the characterization of Roman wall paintings, where both inorganic and organic materials are simultaneously present.
\end{abstract}

Keywords: Roman wall paintings, In situ investigation, Molecular spectroscopy, X-ray fluorescence, Pigments, Domus aurea

\section{Introduction}

Nero's (37-68 AD) Domus Aurea was an enormous complex extending on the Palatine, Caelium and Esquiline hills. It was built after the fire of $64 \mathrm{AD}$ by Severus and Celer, and decorated by the famous painter Fabullus ([1] XXXV, 120). Preexisting structures were included in the construction, such as Claudian epoch horrea (warehouses, granaries) on the slopes of the Esquiline Hill (Oppium Mons). These rooms were decorated, and later

\footnotetext{
*Correspondence: pmazzol@unict.it

1 Department of Biological, Geological and Environmental Sciences, University of Catania, Catania, Italy

Full list of author information is available at the end of the article
}

abandoned, but the Esquiline wing of the Domus follows their orientation [2].

The whole structure was later obliterated by the construction of Trajan's Baths at the beginning of the second century AD. Its rediscovery and exploration during the Renaissance, limited at the time to less than 15 rooms, strongly affected painters as Pinturicchio, Ghirlandaio, Raphael and Giulio Romano [3-5]. Domus Aurea is nowadays an extraordinary underground archaeological site in the central area of Rome, including more than 150 rooms, one third of which is open to the public, with $30,000 \mathrm{~m}^{2}$ of painted and stuccoed surfaces, maintaining evident traces of Nero's power and culture. An interdisciplinary staff (archaeologists, architects, conservators)
Springer Open

(c) The Author(s) 2020. This article is licensed under a Creative Commons Attribution 4.0 International License, which permits use, sharing, adaptation, distribution and reproduction in any medium or format, as long as you give appropriate credit to the original author(s) and the source, provide a link to the Creative Commons licence, and indicate if changes were made. The images or other third party material in this article are included in the article's Creative Commons licence, unless indicated otherwise in a credit line to the material. If material is not included in the article's Creative Commons licence and your intended use is not permitted by statutory regulation or exceeds the permitted use, you will need to obtain permission directly from the copyright holder. To view a copy of this licence, visit http://creativeco mmons.org/licenses/by/4.0/. The Creative Commons Public Domain Dedication waiver (http://creativecommons.org/publicdomain/ zero/1.0/) applies to the data made available in this article, unless otherwise stated in a credit line to the data. 
guarantees maintenance, safety and accessibility to the public. At the beginning of 2019, while installing scaffoldings in room 72 (Fig. 1), through a narrow opening in the North wall of room 72, the decorated barrel vault and back wall of another room appeared. Good quality whitebackground "fourth style" paintings cover all the visible surfaces, the remainder being filled with soil and rubble. The landscape with a delicate temple and a mythological figure on the North wall allowed to denominate this space as the "Sphinx room" (room 72/bis). Even though some signatures from the eighteenth to nineteenth century are present in the vicinity of the "entrance" to the Sphinx room and testify that somebody visited the room already, it was absent from the archaeological publications concerning the Domus Aurea, making this re-discovery an exceptional event.

As it concerns roman paintings, common pigments were ochres $\left(\mathrm{Fe}_{2} \mathrm{O}_{3} \cdot \mathrm{FeOOH} \cdot \mathrm{Fe}_{3} \mathrm{O}_{4}\right.$ yellow, red, purple, brown), lead white $\left(2 \mathrm{PbCO}_{3} \cdot \mathrm{Pb}(\mathrm{OH})_{2}\right)$, red lead $\left(\mathrm{Pb}_{3} \mathrm{O}_{4}\right)$, massicot $(\mathrm{PbO})$, green earths (glauconite $(\mathrm{K}, \mathrm{Na})\left(\mathrm{Fe}^{3+}, \mathrm{Al}, \mathrm{Mg}\right)_{2}(\mathrm{Si}, \mathrm{Al})_{4} \mathrm{O}_{10}(\mathrm{OH})_{2}$ and celadonite $\left.\mathrm{K}\left[\left(\mathrm{Al}, \mathrm{Fe}^{3+}\right),\left(\mathrm{Fe}^{2+}, \mathrm{Mg}\right)\right]\left(\mathrm{AlSi}_{3}, \mathrm{Si}_{4}\right) \mathrm{O}_{10}(\mathrm{OH})_{2}\right)$, chalk $\left(\mathrm{CaCO}_{3}\right)$. Carbon-based blacks $(\mathrm{C})$ and manganese oxides $\left(\mathrm{Mn}_{\mathrm{x}} \mathrm{O}_{\mathrm{y}}\right)$ were used for black. Precious pigments were also used in important rooms [6-8], as for example cinnabar $(\mathrm{HgS})$, azurite $\left(2 \mathrm{CuCO}_{3} \cdot \mathrm{Cu}(\mathrm{OH})_{2}\right)$, malachite $\left(\mathrm{CuCO}_{3} \cdot \mathrm{Cu}(\mathrm{OH})_{2}\right)$, and some organic dyes (indigo, Tyrian purple). A synthetic pigment, Egyptian blue $\left(\mathrm{CaCuSi}_{4} \mathrm{O}_{10}\right)$, was also employed [8, 9]. As Latin authors do not provide clear indications on the painting technique [10], it appears that both fresco, mezzo fresco and secco were used to apply pigments [6, 8], often together. Craftsmen's skills, local availability, the patron's wishes and budget, the room's size and purpose all had an impact on the wall preparation and on the painter's palette $[6-8,11-15]$. A hierarchy in pigments' use among different rooms as well as inside a single space is testified not only in the Domus Aurea [7], but also in Etruscan tombs [16]. In order to identify the pigments, a multianalytical approach based on complementary techniques is often beneficial $[7,17-24]$, with the availability of portable instrumentation being necessary for minimizing the impact of analyses on the archaeological record. Nevertheless, logistic challenges related to in situ investigations need to be taken into account, as they negatively affect the instrumental performances and the obtainable results. These include time constraints, and non-ideal working conditions: scaffoldings to reach the painted surface with portable instrumentation, lack of electrical wiring both for lighting and power supply, unstable

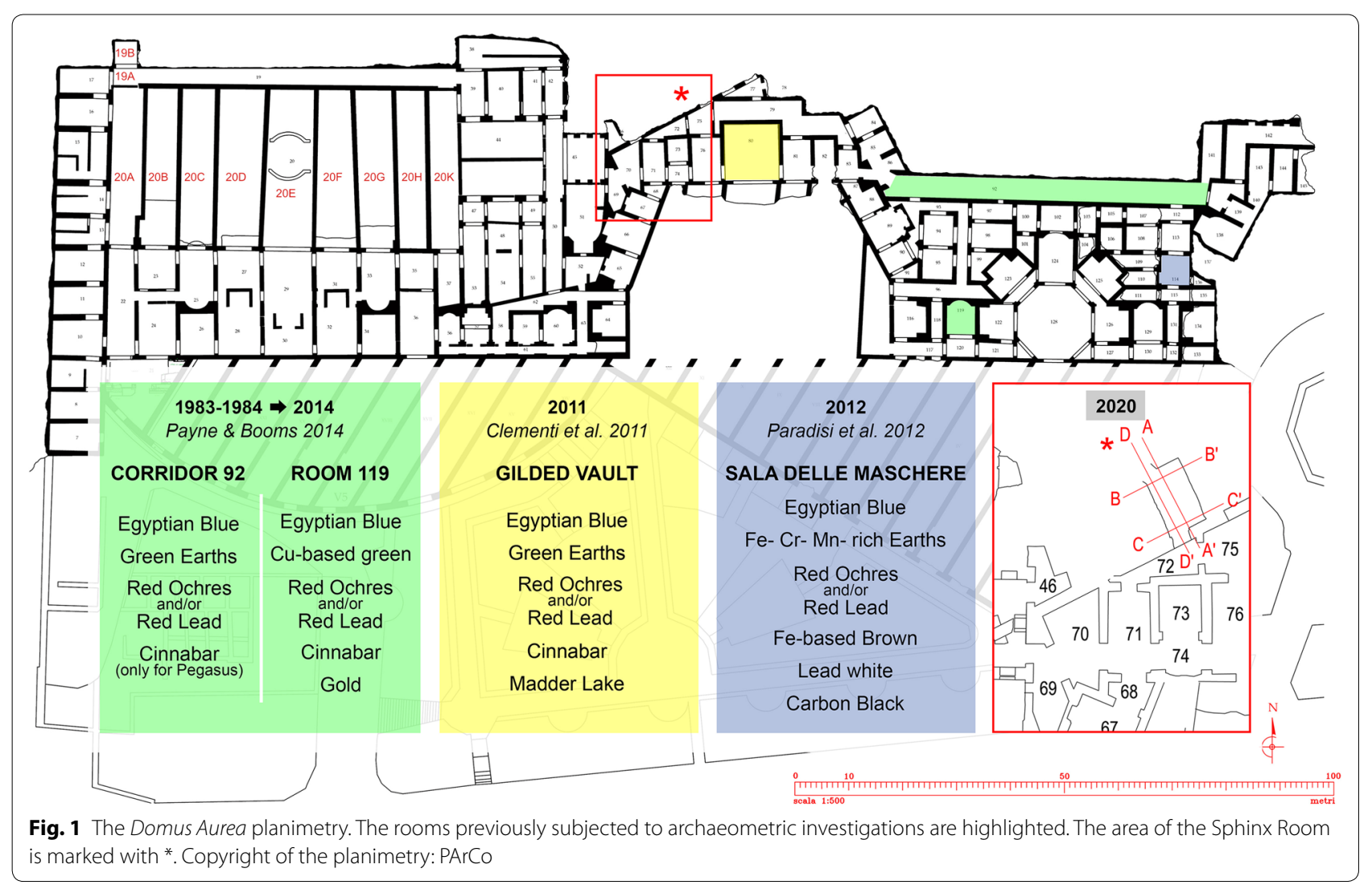


positioning, dust and humidity. As it concerns data interpretation and archaeometrical comparisons, pigment pots and wall paintings have started to be systematically subjected to archaeometrical investigations only recently [25], with the Rome area under-represented in literature (see [26], and references therein), in comparison to the provinces.

To our knowledge, investigations on Domus Aurea decorated surfaces were carried out mainly to address conservation issues [23, 27-30], while the studies concerning the mural paintings composition aimed at understanding the pigments and painting techniques employed are very few [7, 23, 24] (Fig. 1). The study of the decoration of the Gilded Vault (room 80, Fig. 1) by Clementi et al. [24] revealed a rich palette composed of Egyptian blue, green earth, red ochre, cinnabar, madder lake, often present as complex blends and in successive layers. Information on the painting technique could not be obtained in situ.

The in situ investigation of the Sala delle Maschere paintings (Room 114, Fig. 1), defined as frescoes, [23], revealed lead white, iron- (red ochre) and/or lead- (red lead) based compounds for different shades of red, Egyptian blue, iron- chromium- and manganese-rich earths for green, iron-based brown, and carbon black. Conservation issues were highlighted in the form of gypsum, carbonates, nitrates, silicates and organic matter.

Payne and Booms [7] report on wall paintings fragments of Domus Aurea in the British Museum since 1908. They distinguish two palettes of pigments and different styles: in Corridor 92 a less refined style is obtained with red ochre/red lead mixtures, Egyptian blue and green earths, with the only exception of cinnabar usage for a Pegasus figure; Room 119 (Fig. 1) is painted in a more polished style with the use of cinnabar, iron- and leadbased reds, Egyptian blue, copper-based green, and gold.

The present study, which is included in the wider project "Non-destructive analytical studies at Parco Archeologico del Colosseo (Rome, Italy)", aims to increase the knowledge on the mural paintings of Domus Aurea, taking advantage of the recent discovery of the Sphinx Room. The objectives of the study include the comparison with what reported in literature about Domus Aurea and other coeval decorated surfaces and the investigation about the potential hierarchical use of pigments on the walls. This will be done starting from the definition of the raw materials and techniques employed. Apart the pigment palette, attention will be given to the potential presence of organic binders, which is a much-debated question in the literature, but not yet investigated in the rooms of Domus Aurea. This often leads to automatically thinking of its mural paintings as frescoes. The adopted methodological approach prioritizes a non-invasive investigation by means of portable instrumentations
(X-Ray fluorescence (pXRF), Raman and Diffuse Reflectance Infrared Fourier Transform (DRIFT) spectroscopy), followed by dedicated minimally invasive or/ and micro-destructive laboratory analyses (Raman and Fourier Transform Infrared Spectroscopy-Attenuated Total Reflectance (FTIR-ATR spectroscopy)). The comparison of Raman and infrared portable vs. laboratory instrumentations performances is useful to assess the efficiency of the former and to plan future analytical campaigns. Finally, thanks to the integrated methodology acquiring both elemental and molecular information, the advantages of each analytical technique allow to mutually overcome the drawbacks of the others, thus achieving significant results in a precious but challenging context of analysis as such.

\section{Materials and methods The "Sphinx Room"}

The painting decorations of the room vault $(4 \times 8 \mathrm{~m} \mathrm{ca}$.), located at the back of the Gilded Vault Room, slightly towards North-West, are well visible and generally well kept; nevertheless, soon after the discovery, it was considered necessary to consolidate and secure the plaster layer.

As a whole, the decoration is made up of figures comparable to those visible in other rooms of the Domus Aurea, such as Corridor 92. This room, attributed to the so called "Workshop A", and dated to 65-68 AD [31], has also been studied by archaeometric techniques [7]. Workshop A's paintings reveal stylistic and qualitative differences depending on the importance and the position of the spaces that are decorated. The style is characterized by predominant white backgrounds with delicate figures and festoons, with a bright and airy effect that is well-suited for smaller and darker rooms.

The decoration of the barrel vault (Additional file 1: SM1a) is arranged within a triple red frame and divided into different compartments by yellow and/or red bands, all bordered by an external perimeter rectangle made of golden-yellow bands with red vegetal ornamental motifs, repeated at the corners in curved bands. Within this framework, different anthropomorphic and zoomorphic figures are elegantly and skillfully portrayed with thick strokes: the central one emerges from a tuft and is armed with quiver, sword and shield against a panther, the others represent centaurs and Pan, one holding a lituus (crooked wand), another with musical instruments. Outside the external rectangle, along the short sides, real and imaginary stylized aquatic creatures follow one another. The decoration of the vault, especially in the central part [in this work called "Vault" and distinguished from the East (Additional file 1: SM1b) and West (Additional file 1: SM1c) walls], is further embellished by vegetal motifs 
such as slender wreaths and tufts with green, yellow and red stems and small leaves composing a surreal landscape where small birds are portrayed in different poses.

Incisions obtained with a snap line on wet plaster and a compass [32] are well visible (in raking light) along the horizontal bands and corners of the wider frame of the vault decoration (Additional file 2: SM2). On the North wall, a golden ritual patera and half garland hang above an imaginary temple with slender columns. On the left, a solitary sphinx, after which the room has been named, stands out against a baetylus (conic object with various meanings) (Additional file 1: SM1d). The room presents extensive salt efflorescences and biocolonization, particularly evident in the North wall.

\section{Analytical approach Portable instrumentation}

The analytical approach preferred the in situ investigation with the employ of complementary portable techniques. This was aimed both at preserving the pristine environment and at gaining as much information as possible on the overall polychromy, both from an elemental and from a molecular point of view. The transport of the instrumentation was challenging and could be possible only thanks to the small dimensions and compactness of the devices, as the room is still filled with rubble and accessible through a narrow opening, after various flights of stairs. The analytical conditions were as much hard: irregular, sloping floor and low space under the vault (maximum height of ca. $140 \mathrm{~cm}$ ); power supply issues both for lighting and instruments operation; peculiar humidity and temperature microclimate ([28] reports relative humidity of $80-100 \%$ ) (Fig. 2a, https:// www.youtube.com/watch? $=$ wBSZuh5GsEw). The two former strongly limited the possibility for the operators to move around freely and imposed to hold the instruments by hand while sitting/kneeling; in addition to these geometric aspects, the latter prevented the installation of the DRIFTS instrument inside the room due to the well-known water interference in FTIR. A makeshift laboratory was set up in the storage room to be able to characterize by DRIFTS some bigger fragments from the room waiting for reintegration on the West wall continuation of the Vault: this allowed to analyze white, yellow, red and black colors (Frag1 and Frag2 in Fig. 3). The employed approach is based on the following:

- PXRF analyses were performed in air with a battery-operated Bruker Tracer IV-SD system equipped with a Rh target X-ray tube with Pd slits and a Silicon Drift Detector. Measurements were carried out in air. For each area, one spectrum of $30 \mathrm{~s}$ (live time) was acquired operating the tube at $40 \mathrm{kV}$ and $17 \mu \mathrm{A}$, with a $304.8 \mu \mathrm{m}$ aluminum $+25.4 \mu \mathrm{m}$ titanium filter, which is the setting normally used for trace element analysis $(Z>19)$. S1PXRF software was used for the spectra interpretation, while quantitative data were obtained by fundamental parameters (PyMCA software [33]), with configuration files adapted for the Tracer IV-SD specifications and considering attenuation from a typical plaster composition. Elemental data were corrected using the best fit method calculated on 39 international minerals and rocks standards. Lower limits of detection (LLD) were obtained by the manufacturer, and reported data are above these values. Quantitative pXRF abundances are affected by errors due to the finite thickness of the pigmented layer, the presence of surface deposits, and the irregular surface of the paint. We consider these errors common to all the spectra, allowing us to compare the results obtained on different fragments.
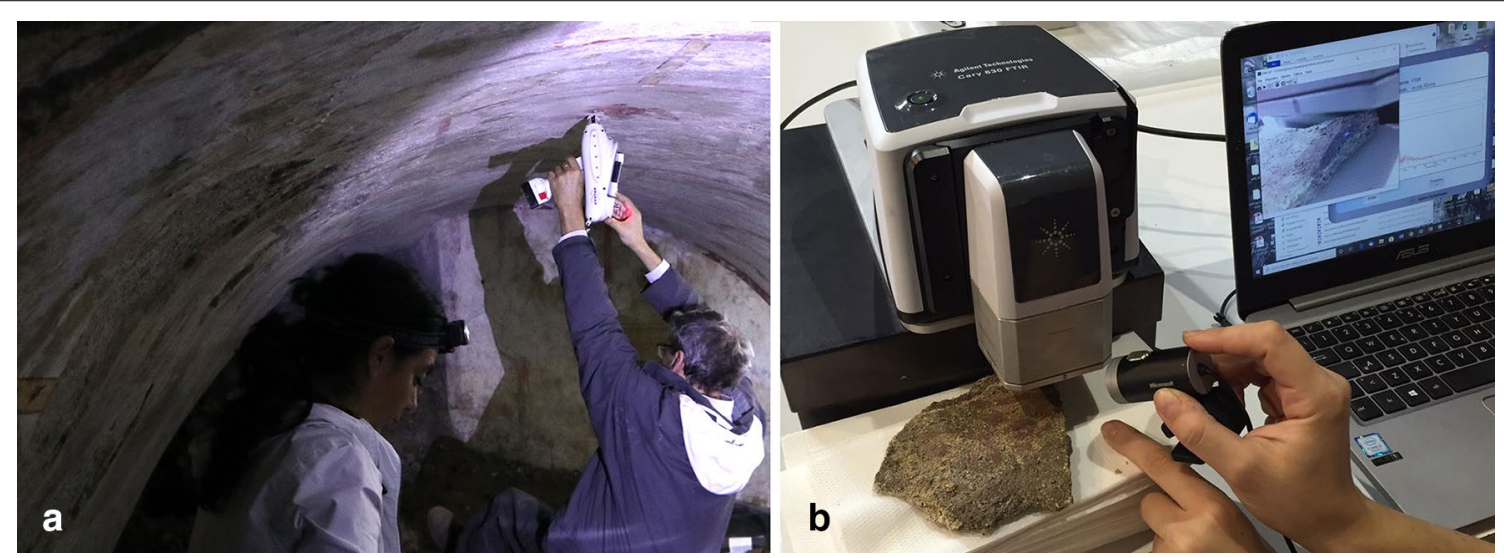

Fig. 2 a Detail of the in situ XRF analyses, $\mathbf{b}$ makeshift laboratory for DRIFTS characterization 


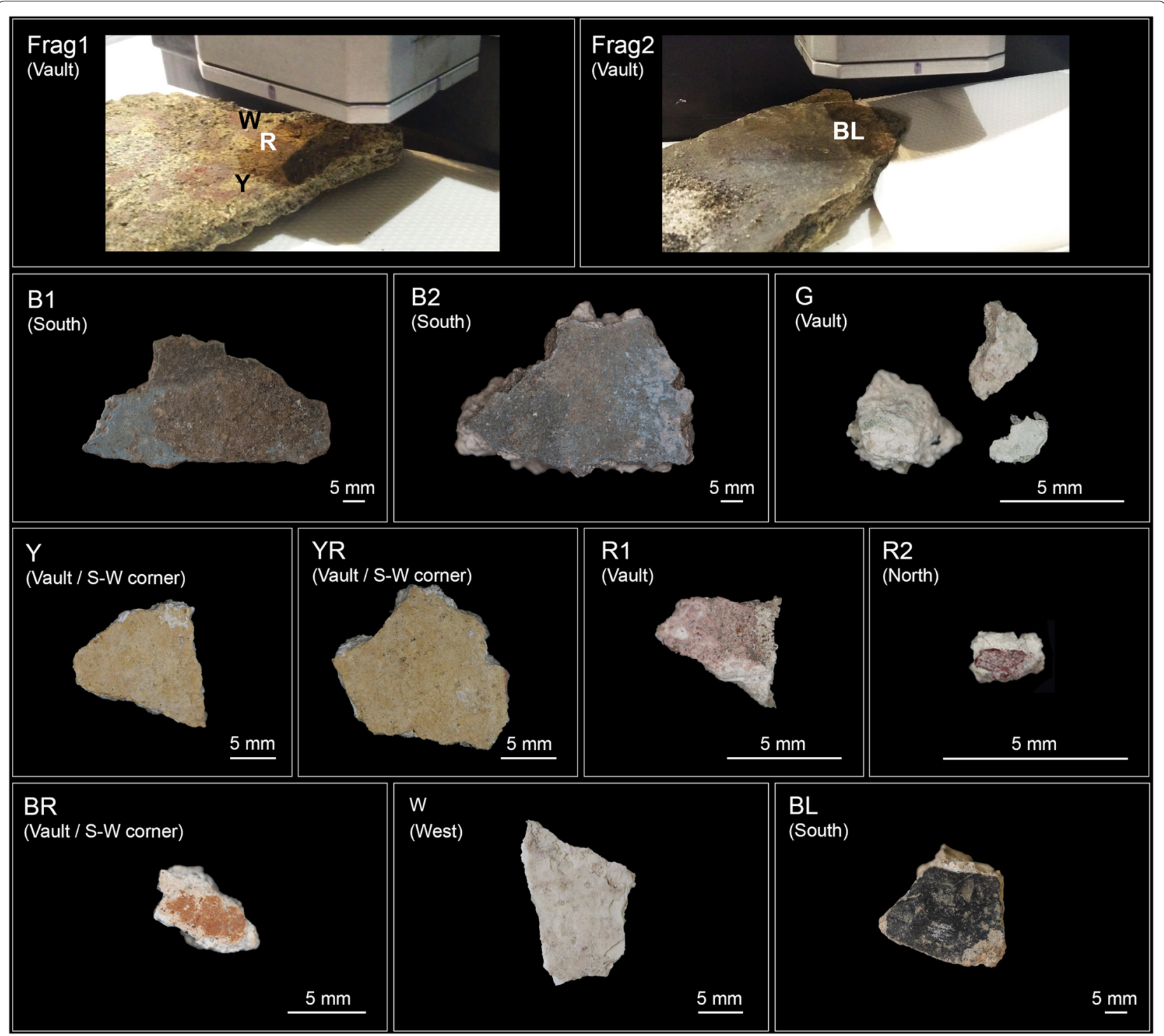

Fig. 3 Photos of the larger fragments investigated in situ with DRIFTS (Frag1, Frag2) with the analyzed spots (White, Red, Yellow, BLack), and of the smaller ones found in the debris (Blue1, Blue2, Yellow, Yellow-Red, Brown, White, BLack) or scraped from the walls (Greyish, Red1, Red2). The relative walls are indicated in brackets

- Raman measurements were carried out using an i-Raman ${ }^{\circledR}$ Plus spectrometer (B\&W Tek), equipped with a $785 \mathrm{~nm}$ diode laser with a maximum power of $420 \mathrm{~mW}$ connected to optical fibers and to a BAC102 probe (B\&W Tek Inc.): the spot size is $85 \mu \mathrm{m}$ at a working distance of $5.90 \mathrm{~mm}$ guaranteed by the presence of a tubular spacer. The laser power can be modulated thanks to density filters ranging from 0 to $100 \%$. The radiation is dispersed by a holographic grating on a 2048 pixels CCD array (cooling temperature: $-2{ }^{\circ} \mathrm{C}$ ); the nominal spectral resolution is of $4.5 \mathrm{~cm}^{-1}$. The operating conditions varied according to the arising fluorescence, ranging from 0.1 to $10 \mathrm{~s}$ and from 10 to 100 accumulations, using filters allowing from 1 to $10 \%$ of the incident laser to reach the spot under analysis. Raman spectra were treated using LabSpec. A reference background spectrum, in addition to dark subtraction was employed to discriminate between artifacts and Raman signals: only the latter are indicated in the text.

- DRIFT spectra were acquired using a modified Agilent Cary 630(R), for which Madatec srl developed a new accessory for Non-Contact Measures (MadaIR) 
(working distance $=25 \mathrm{~mm}$ ). Due to the small footprint $(16 \times 31 \times 13 \mathrm{~cm})$ and total weight $(4.8 \mathrm{~kg})$, the complete instrument can be either mounted on a tripod with xyz translator, or used on an elevated support to study samples lying on a table (Fig. 2b). It uses a Michelson Interferometer and covers the spectral range $650-5500 \mathrm{~cm}^{-1}$ with a spectral resolution of $4 \mathrm{~cm}^{-1}$ and an investigated diameter of about $3 \mathrm{~mm}$. The system is controlled by the software Agilent MicroLab PC. The spectra were acquired averaging 360 scans (about $3 \mathrm{~min}$ ). The spectra are shown with the intensity unity defined as absorbance $A^{\prime}$ $\left(\mathrm{A}^{\prime}=\log (1 / \mathrm{R})\right)$.

\section{Laboratory instrumentation}

Fragments were collected from the debris in the vicinity of the painted walls assuming that the material came from the wall itself and was not part of the room's filling (B1, B2, Y, YR, BR, W, BL in Fig. 3); smaller fragments were scraped from already mechanically damaged edges of the paintings (G, R1, R2 in Fig. 3). All of them were subjected to laboratory analysis to complement the in situ ones. They were analyzed with the following instrumentation:

- For the micro-Raman laboratory investigation, a Jasco NRS3100 spectrometer equipped with a microscope with $50 \times$ LWD and $100 \times$ objectives and two solid state laser sources (532 and $785 \mathrm{~nm}$ ) was employed. It is provided with a Notch filter and a Peltier-cooled $\left(-55^{\circ} \mathrm{C}\right) 1024 \times 128 \mathrm{CCD}$. Laser power is controlled by means of neutral optical density filters, to avoid heating effects. With the $1800 \mathrm{gr} / \mathrm{mm}$ grating, a spectral resolution of $1 \mathrm{~cm}^{-1}$ is reached, while the minimum lateral and depth resolutions can be as low as $1 \mu \mathrm{m}$ by means of a confocal hole. The system was calibrated using the $520.7 \mathrm{~cm}^{-1}$ Raman band of silicon before each experimental session. The parameters of acquisition were adjusted for each sample taking into account its color and the arising fluorescence. The power values were kept between 0.3 and $2.5 \mathrm{~mW}$, the time between 10 and $60 \mathrm{~s}$ and the accumulations between 3 and 100 .

- For laboratory infrared spectroscopy investigation, a Thermo Fisher Scientific Nicolet 380 FT-IR spectrometer with a Smart Orbit diamond attenuated total reflectance (ATR) cell was used. The spectra were collected at room temperature in the $400-4000 \mathrm{~cm}^{-1}$ range, with $4 \mathrm{~cm}^{-1}$ resolution and averaging 64 scans. A small amount of powder was gently scraped from the pigmented surface of each selected fragment and deposited on the diamond to be analyzed.

\section{Results \\ Portable instrumentation \\ Elemental analysis_portable X-ray Fluorescence}

In Table 1 the results of in situ pXRF analyses are reported by color (the term greyish encompasses a variety of dull green to blue shades, present in the leaves and the swirl under the central figure of the vault (Fig. 4a) and the festoon, Sphinx and temple on the North wall (Fig. 4b)). PXRF spectra of selected points are shown in Fig. 5. PXRF was used to obtain qualitative information on the key elements associated with traditional pigments in use during Roman times, mainly based on $\mathrm{Fe}, \mathrm{Cu}, \mathrm{Pb}$ (in bold in Table 1). Some relevant trace elements, such as for example As and Sn, were as well considered for obtaining further information on the manufacturing and sourcing of pigments.

XRF results for all the studied spots (Table 1, Fig. 5) show the intense signal of $\mathrm{Ca}$ and the ubiquitous presence of $\mathrm{K}$. The presence of Ba should also be highlighted on the North wall, especially in the Sphinx (points 7, 12, 13), festoon decoration (points 4 and 5), and on the upper part of the temple (points 6 and 11) (Table 1, Fig. 5).

As it concerns key elements, all the studied points show variable quantities of $\mathrm{Fe}$, and, for many of them, also of $\mathrm{Pb}$ (Fig. 6a). The highest $\mathrm{Cu}$ contents are clearly associated with the blue $(1,2)$ and points of the vault (greyish 8-10 and red 20-24) (Table 1).

The blue areas have fairly similar, and relatively high, $\mathrm{Cr}$ content, while only point 2 shows Sn (Table 1). Cr is also present in all the greyish samples from the vault (points $8-10)$ and point 10 has also relatively high $\mathrm{Pb}$.

Fe presence is significant both in the greyish areas and in the yellow and red points. Different trends are evident when comparing the $\mathrm{K}$ and Fe content of different hues (Fig. 6b).

Yellows, orange and reds contain either $\mathrm{Fe}$ or $\mathrm{Pb}$, or mixtures of the two. The orange point 17 is $\mathrm{Pb}$-based and $\mathrm{Sn}$ rich. As it concerns the vault and eastern wall, with the exception of points 21 and 23, the red and yellows suggest the use of mixtures of $\mathrm{Pb}$ - and Fe-containing pigments. The highest $\mathrm{Pb}$ contents (Fig. 6a) in red areas belong to points 22 and 24, on the vault, and to point 20 on the eastern wall. Point 24 is the only one with detectable amounts of $\mathrm{V}$. On the other hand, Pb-rich yellows (12 and 13) and orange (17) are all found on the North wall. Higher Fe contents are observed in red and yellow areas, with no wall-specific trends (Fig. 6a). 
Table 1 pXRF chemical characterization of the Sphinx Room

\begin{tabular}{|c|c|c|c|c|c|c|c|c|c|c|c|c|c|c|c|c|c|}
\hline \multicolumn{3}{|c|}{ LLD (ppm) } & \multirow{2}{*}{$\begin{array}{l}75 \\
\mathrm{~K}\end{array}$} & \multirow{2}{*}{$\begin{array}{l}75 \\
\mathrm{Ca}\end{array}$} & \multirow{2}{*}{$\begin{array}{l}75 \\
\mathrm{Ti}\end{array}$} & \multirow{2}{*}{$\begin{array}{l}75 \\
v\end{array}$} & \multirow{2}{*}{$\begin{array}{l}10 \\
\mathrm{Cr}\end{array}$} & \multirow[b]{2}{*}{$\mathrm{Fe}$} & \multirow{2}{*}{$\begin{array}{l}60 \\
\mathrm{Cu}\end{array}$} & \multirow[b]{2}{*}{$\mathbf{R b}$} & \multicolumn{2}{|l|}{1} & \multirow{2}{*}{$\begin{array}{l}3 \\
\text { As }\end{array}$} & \multirow{2}{*}{$\begin{array}{l}1 \\
\text { Sn }\end{array}$} & \multirow{2}{*}{$\begin{array}{l}75 \\
\mathrm{Ba}\end{array}$} & \multirow{2}{*}{$\begin{array}{l}3 \\
w\end{array}$} & \multirow{2}{*}{$\begin{array}{l}3 \\
\mathrm{~Pb}\end{array}$} \\
\hline Color & Wall & Point & & & & & & & & & $\mathrm{Sr}$ & $\mathrm{Zr}$ & & & & & \\
\hline Blue & $S$ & 1 & 1701 & 26,030 & 113 & bld & 160 & 626 & $1,353,709$ & 33 & 1857 & 15 & 12 & 1 & bld & 19 & 126 \\
\hline Blue & $S$ & 2 & 1173 & 26,360 & 98 & bld & 152 & 425 & $1,290,183$ & 31 & 1825 & 10 & 16 & 98 & 122 & 9 & 89 \\
\hline Greyish & $\mathrm{N}$ & 3 & 489 & 78,250 & bld & bld & bld & 54 & bld & 18 & 324 & 19 & bld & 159 & bld & 7 & 38 \\
\hline Jreyish & $\mathrm{N}$ & 4 & 1409 & 54,300 & bld & bld & bld & 274 & bld & 12 & 572 & 13 & bld & 76 & 739 & 4 & 49 \\
\hline Greyish & $N$ & 5 & 1052 & 68,940 & bld & bld & bld & 233 & bld & 26 & 584 & 23 & 3 & 126 & 473 & 8 & 51 \\
\hline Greyish & $\mathrm{N}$ & 6 & 437 & 81,910 & bld & bld & bld & 111 & bld & 17 & 400 & 12 & bld & 193 & 271 & 11 & 55 \\
\hline Greyish & $N$ & 7 & 531 & 51,650 & 347 & bld & bld & 265 & bld & 19 & 501 & 14 & bld & 40 & 4539 & bld & 58 \\
\hline Greyish & vault & 8 & 2666 & 46,040 & 81 & bld & 17 & 703 & 71 & 43 & 933 & 16 & 5 & 28 & bld & bld & 37 \\
\hline Greyish & vault & 9 & 1731 & 54,650 & bld & bld & 11 & 414 & 2424 & 28 & 861 & 18 & 6 & 80 & bld & 9 & 44 \\
\hline Greyish & vault & 10 & 1416 & 39,570 & bld & bld & 15 & 450 & 557,549 & 16 & 968 & 6 & 24 & 45 & bld & 10 & 434 \\
\hline Yellow & $\mathrm{N}$ & 11 & 601 & 81,580 & bld & bld & bld & 100 & bld & 22 & 408 & 20 & bld & 158 & 196 & bld & 50 \\
\hline Yellow & N & 12 & 525 & 51,790 & 187 & bld & bld & 458 & 96 & 18 & 703 & 13 & 182 & 39 & 2702 & bld & 2255 \\
\hline Yellow & $\mathrm{N}$ & 13 & 423 & 43,650 & 242 & bld & bld & 908 & 352 & 17 & 607 & 23 & 117 & 5 & 2992 & bld & 1733 \\
\hline Yellow & $\mathrm{E}$ & 14 & 362 & 18,830 & bld & bld & bld & 162 & bld & 10 & 739 & 8 & bld & 15 & bld & 15 & 33 \\
\hline Yellow & vault & 15 & 475 & 24,800 & bld & bld & bld & 724 & 134 & 12 & 569 & 8 & bld & 48 & bld & bld & 55 \\
\hline Yellow & vault & 16 & 765 & 35,890 & bld & bld & bld & 711 & 1117 & 20 & 698 & 12 & bld & 27 & bld & 3 & 56 \\
\hline Orange & $\mathrm{N}$ & 17 & 284 & 58,720 & 89 & bld & bld & 176 & bld & 6 & 292 & 9 & 517 & 115 & 938 & bld & 5857 \\
\hline Red & $\mathrm{N}$ & 18 & 358 & 76,820 & bld & bld & bld & 237 & bld & 13 & 325 & 16 & 62 & 31 & bld & 18 & 54 \\
\hline Red & $N$ & 19 & 468 & 77,710 & bld & bld & bld & 210 & bld & 14 & 344 & 15 & 78 & 121 & bld & 16 & 61 \\
\hline Red & $E$ & 20 & 577 & 51,410 & 80 & bld & 10 & 1609 & 99 & 18 & 541 & 16 & 797 & 38 & bld & 11 & 3135 \\
\hline Red & vault & 21 & 936 & 50,360 & bld & bld & bld & 1861 & 98 & 21 & 1043 & 15 & 971 & 35 & bld & 69 & 37 \\
\hline Red & vault & 22 & 463 & 45,290 & bld & bld & 11 & 857 & 2514 & 6 & 715 & 9 & 396 & 11 & bld & 4 & 3668 \\
\hline Red & vault & 23 & 977 & 55,940 & bld & bld & bld & 839 & 367 & 19 & 1102 & 12 & 85 & 48 & bld & 13 & 275 \\
\hline Red & vault & 24 & 489 & 45,280 & bld & 90 & bld & 925 & 578 & 12 & 1027 & 6 & 1700 & 11 & bld & 26 & 4853 \\
\hline
\end{tabular}

Data are expressed as ppm. LLD provided by the pXRF manufacturer are reported; bld = below limit of detection. The sample names correspond to Fig. 4. Elements in bold are related to common Roman age pigments

The dark red points 18 and 19 measured on the column of the temple (North wall) show both low $\mathrm{Pb}$ and low Fe: as can be seen from Fig. 4b, a thick yellowish-brown patina affects the area and could have hampered the collection of the XRF spectra.

In Fig. $7 \mathrm{~d}$ and e, As content is plotted against $\mathrm{Fe}$ and $\mathrm{Pb}$ respectively. In the first one, only two points (17, orange, and 24, red) deviate from the trend, while in the second graph the $\mathrm{Pb}$-containing points show and enrichment in As. Of the low- $\mathrm{Pb}$ group, only point 21 , which is iron based, shows high levels of As.

\section{Molecular spectroscopy-Raman}

The in situ Raman analyses (Table 2) often show calcite $\left(\mathrm{CaCO}_{3}\right)$, characterized by peaks at $158,282,714$ and $1086 \mathrm{~cm}^{-1}$ [34] and better visible in the spectrum of a white area (Fig. 8e).

Together with the recurring symmetric Edge filter noise, the occurrence of two phenomena further hindered the revelation of the pigments' Raman spectra: high fluorescence due to the conservation state of the surfaces, and the arising of very intense luminescence bands.

These latter appear in the spectra of greyish, yellow and orange spots acquired on the North wall and on another green area (Fig. 8a-d): they seem to characterize earth-based pigments. The bands are centered at about $1430 \mathrm{~cm}^{-1}$, corresponding to ca. $884 \mathrm{~nm}$ considering the exciting laser at $785 \mathrm{~nm}$. The $880 \mathrm{~nm}$ line could be due to the presence of $\mathrm{Nd}^{3+}$ in calcite, apatite $\mathrm{Ca}_{5}\left(\mathrm{PO}_{4}\right)_{3}$ anhydrite $\left(\mathrm{CaSO}_{4}\right)$ or albite $\left(\mathrm{NaAlSi}_{3} \mathrm{O}_{8}\right)$ [35], all compounds possibly present in, or over, the pigmented material. In these spectra (Fig. 8b-d) the signature of a calcium oxalate phase (weddellite) is visible in the low wavenumber region with the signals at 188 and $909 \mathrm{~cm}^{-1}$ [36]: it could be due to biological activity or to the presence of organic binders [37,38].

The spectrum in Fig. $8 \mathrm{f}$ was acquired on a red spot and shows, apart calcite signature, a weak signal probably identified as hematite $\left(228 \mathrm{~cm}^{-1}\right)$ [39]. 

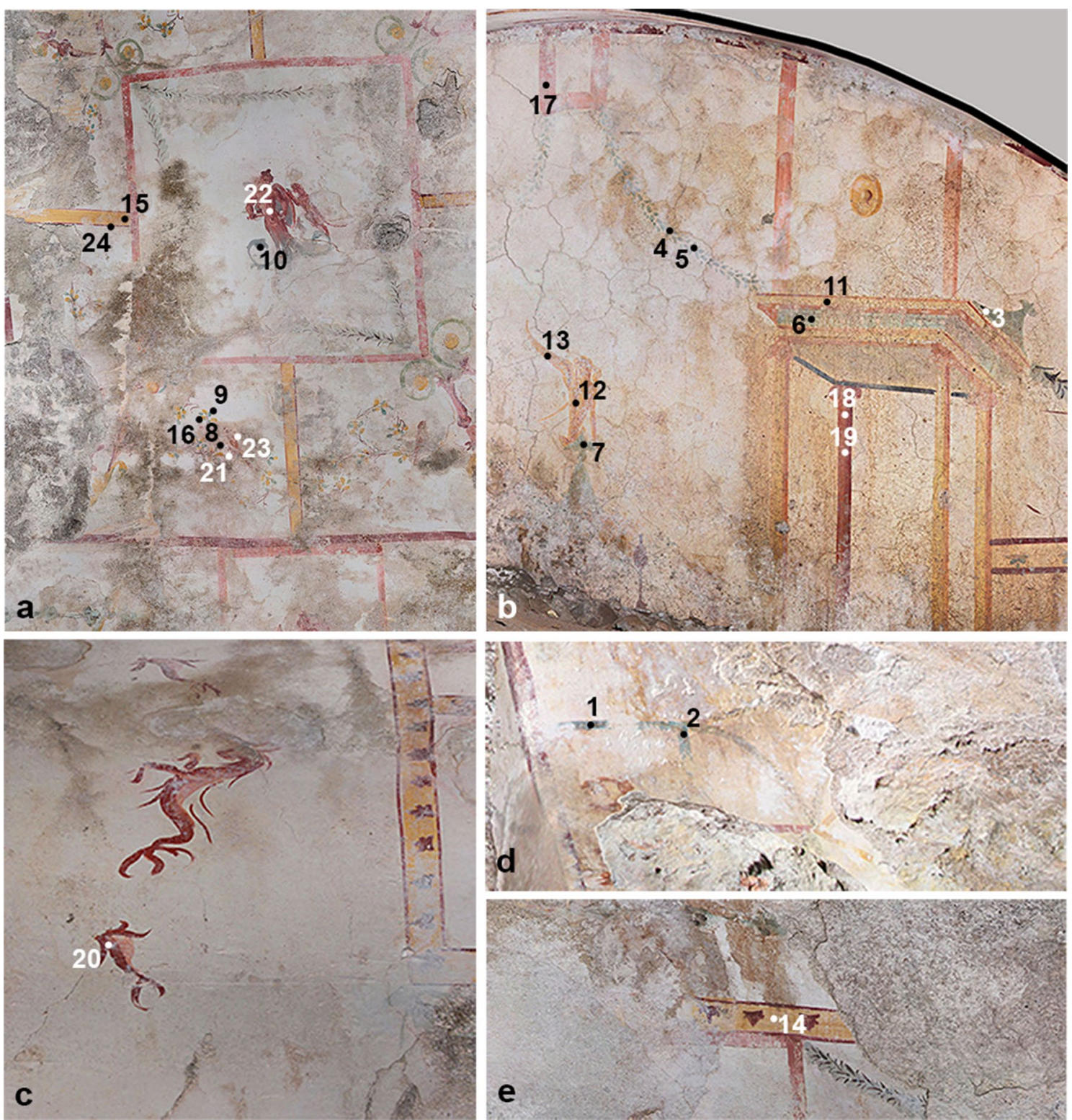

Fig. 4 Portable XRF spots of analysis on a vault, b North wall, $\mathbf{c}$ East wall, $\mathbf{d}$ South wall, e West wall

\section{Molecular spectroscopy - diffuse Reflectance Infrared Fourier Transform spectroscopy}

The DRIFT analyses were carried out in situ on large fragments to be reintegrated and provided by the restorers, including white, yellow, red, and black colors (Fig. 3). For blue (B1, B2), greyish (G), brown (BR), and red (R2), the tiny fragments employed for the other laboratory investigations were analyzed (Fig. 3). All the DRIFT spectra obtained are shown in Figs. 9 and 10 and the wavenumber positions are listed in Table 2.

The spectrum relative to the white area (Fig. 9c) clearly shows the features of calcite: $4270 \mathrm{~cm}^{-1}$ $\left(3 v_{3}\left(\mathrm{CO}_{3}\right)^{2-}\right), \quad 2970$ and $2868 \mathrm{~cm}^{-1} \quad\left(2 v_{3}\right)$, $2515+2590 \mathrm{~cm}^{-1}$ doublet $\left(v_{1}+v_{3}\right.$ and/or $2 v_{2}+v_{4}$ $\left.\left(\mathrm{CO}_{3}\right)^{2-}\right), 1795 \mathrm{~cm}^{-1}\left(v_{1}+v_{4}\left(\mathrm{CO}_{3}\right)^{2-}\right), 1400 \mathrm{~cm}^{-1} \mathrm{ca}$. strong absorption $\left(v_{3}\left(\mathrm{CO}_{3}\right)^{2-}\right)$ inverted by the reststrahlen effect, $880 \mathrm{~cm}^{-1}\left(v_{2}\right)$ distorted in a derivative shape [40-43]. The same features are more or less evident in the other DRIFT spectra, especially in that of the black spot (Fig. 9a), and are highlighted with a dotted red line. The band at $2400 \mathrm{~cm}^{-1}$ visible in almost all the DRIFT spectra could be attributed to $\left(\mathrm{CO}_{3}\right)^{2-}$ $v_{1}+v_{3}$ mode but in relation to cerussite $\left(\mathrm{PbCO}_{3}\right)$ rather than calcite: thus, even if at lower wavenumber with 


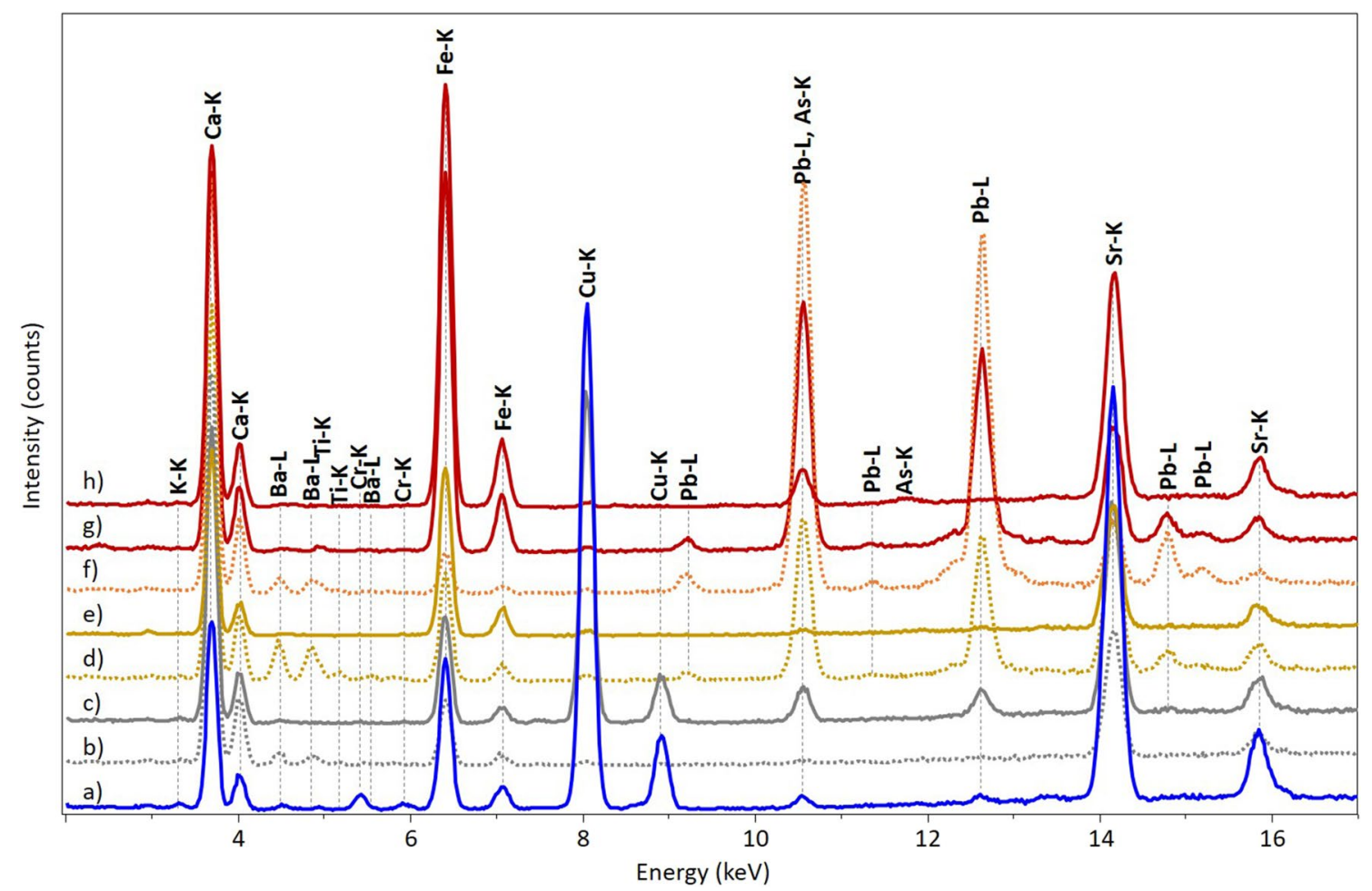

Fig. 5 pXRF spectra of selected spots. The color of the symbol corresponds to the analyzed shade. Dashed spectra are from the North wall. a Point 1; b point 4 ; $\mathbf{c}$ point 10; $\mathbf{d}$ point 12; e point 15; f point 17; $\mathbf{g}$ point $20 ; \mathbf{h}$ point 21

respect to literature $\left(2410 \mathrm{~cm}^{-1}\right.$ [41]) it may lead to think that lead carbonate is often associated to calcium carbonate. However, the proximity of $\mathrm{CO}_{2}$ signature may distort the spectrum in this region.

In Fig. 9e, B2 sample blue pigment's spectrum corresponds to Egyptian Blue: it shows the typical inverted bands at 1170,1060 and $1006 \mathrm{~cm}^{-1}$ and the shoulder at $1250 \mathrm{~cm}^{-1}$ assigned to the double silicate cuprorivaite [41, 44]. On B1 (Fig. 9f) the features of gypsum $\left(\mathrm{CaSO}_{4} \cdot 2 \mathrm{H}_{2} \mathrm{O}\right)$ are also revealed: $2230 \mathrm{~cm}^{-1}\left(2 v_{3}\left(\mathrm{SO}_{4}\right)^{2-}\right.$; $\left.v_{2}+v_{\mathrm{L}} \mathrm{H}_{2} \mathrm{O}\right), 2120 \mathrm{~cm}^{-1} \mathrm{ca} .\left(v_{1}+v_{3}\left(\mathrm{SO}_{4}\right)^{2-}\right)$ and the reststrahlen inverted band at $1140 \mathrm{~cm}^{-1}\left(v_{3}\left(\mathrm{SO}_{4}\right)^{2-}\right)$ [41, 42].

The interpretation of the spectrum of the greyish sample (Fig. 9d) is challenging because it suggests a mixture of pigments. The presence of kaolinite $\left(\mathrm{Al}_{2}\left(\mathrm{Si}_{2} \mathrm{O}_{5}\right)(\mathrm{OH})_{4}\right)$, that can be associated to earths, can be inferred by its fundamental $\mathrm{Si}-\mathrm{O}$ stretching mode included between 1010 and $1100 \mathrm{~cm}^{-1}$ [41], here at about $1065 \mathrm{~cm}^{-1}$ [45]; also, the inverted band at about $1550 \mathrm{~cm}^{-1}$ can be found in all the spectra related to red color in Fig. 10.

The DRIFT spectra acquired on the yellow spots can invariably be represented by that in Fig. 9b. The features are mostly those of calcite to whose spectrum they are almost superimposable. Nevertheless, the kaolin characteristic features at 4524 (combination band $v+\delta \mathrm{OH}$ ),
3690 and $3612 \mathrm{~cm}^{-1}$ (OH stretching) can suggest the usage of yellow ochre [41].

The spectra of two different red spots and a brown one, Frag1_R (Fig. 10c), R2 (Fig. 10b) and BR (Fig. 10a) have all an ochre basis: spectra a) and b) in Fig. 10 show the typical shoulder of pure hematite at $1109 \mathrm{~cm}^{-1}$ [44], spectrum c) displays the already mentioned kaolin band at $4525 \mathrm{~cm}^{-1}$ [41], and all the three of them exhibit an inverted band ranging from 1030 to 1065 that can be attributed to the silicate matrix. The spectra of the red areas too show the peak at $2400 \mathrm{~cm}^{-1}$ probably attributable to cerussite; in addition, especially pronounced in spectrum b, 1740 and inverted $1415 \mathrm{~cm}^{-1}$ bands are also visible: these could be respectively assigned to carbonate ion $v_{1}+v_{4}$ and $v_{3}$ modes typical of cerussite or hydrocerussite $\left(\mathrm{Pb}_{3}\left(\mathrm{CO}_{3}\right)_{2}(\mathrm{OH})_{2}\right)$.

In almost all the spectra, but more evident in Figs. 9f (B1), 9b (Frag1_Y) and 10b (R2) signals are present in the regions of the $\mathrm{CH}$ stretching, around $2900 \mathrm{~cm}^{-1}$ and in the amide I, amide II and amide III ones, respectively at about 1690, 1570 and $1450 \mathrm{~cm}^{-1}$ [41-43, 46], which would lead to infer the presence of a proteinaceous material. Nevertheless, the lime-based matrix or substrate makes this hypothesis weaker, since carbonate bands are overlapped in the $2800-3000 \mathrm{~cm}^{-1}$ region [40] generally 

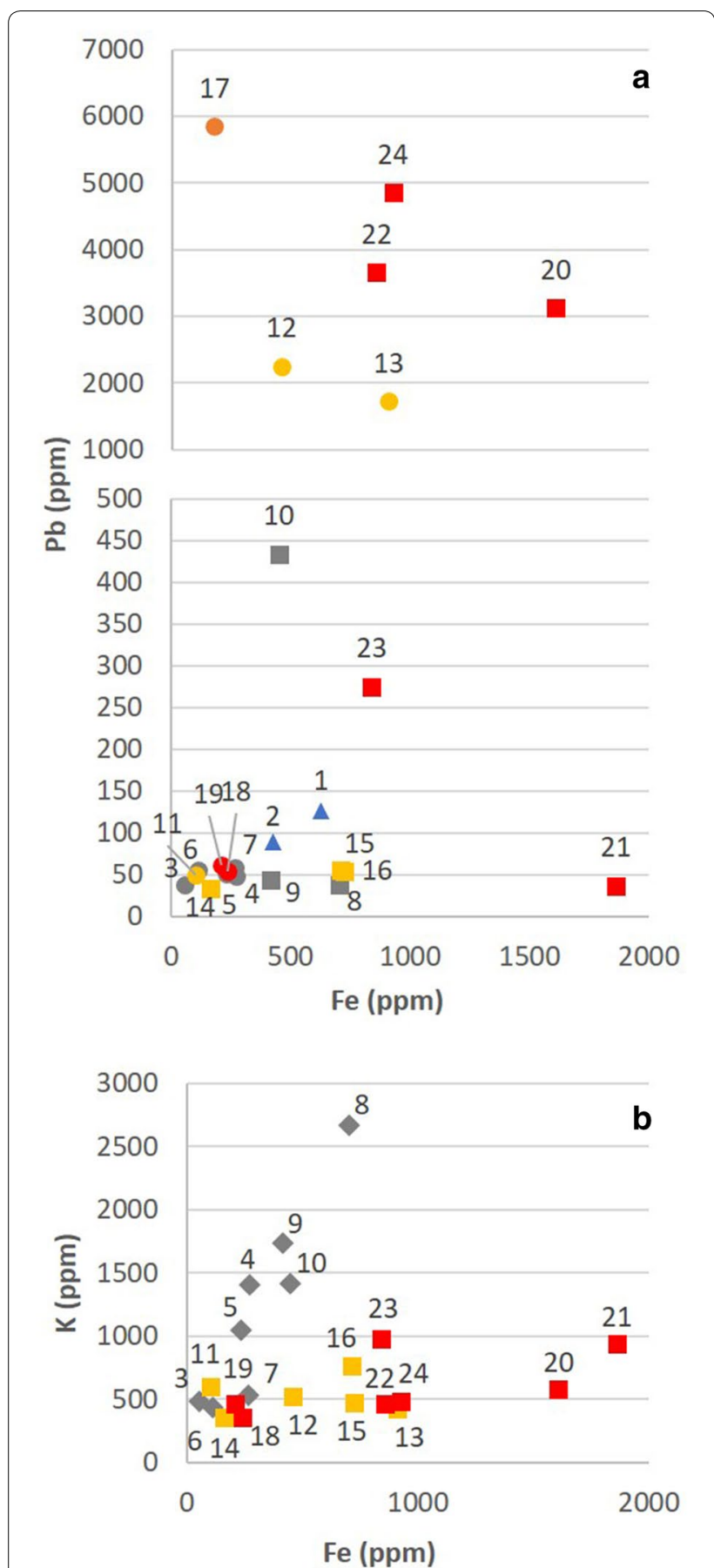

Fig. 6 Bivariate diagrams of Pb vs. Fe (a) and K vs. Fe (b) for all the analyzed spots. The color of the symbol corresponds to the analyzed shade. Squares indicate points on the vault and eastern wall, circles points on the North wall, triangles on the southern one. Diamonds are used when no distinction is made between the vault and North walls' points hindering or distorting the organic binders DRIFT signals [43].

\section{Laboratory instrumentation Molecular spectroscopy-micro-Raman}

The laboratory Raman investigations were carried out both with the 532 and with the $785 \mathrm{~nm}$ lasers: as expected, the former gave the best results for white, black and blue samples, the latter for the yellow, red and earthtones (see Table 2 for all the results).

On the white sample, apart from calcite signature, which was found also in other colors spectra (see Fig. 12a, c), the presence of gypsum was revealed by its principal signal at $1006 \mathrm{~cm}^{-1}$ (Fig. 11b) [34].

The Raman analysis performed on sample B1 allowed to obtain a spectrum only when focusing on a blue particle (Fig. 11a'): the result is compatible with Egyptian Blue $\left(426,1080 \mathrm{~cm}^{-1}\right)$ associated to gypsum $\left(1006 \mathrm{~cm}^{-1}\right)$ (Fig. 11a) [34, 47].

On fragment BL, Raman spectroscopy allowed the identification of a carbon-based pigment with the two typical bands D and $G$ at about 1375 and $1587 \mathrm{~cm}^{-1}$ respectively (Fig. 11d). Comparing the obtained spectrum with those of reference black pigments, a similarity was highlighted with bituminous materials such as asphaltum, Van Dyck Brown and Cassel Earth [48]. The green excitation on the red sample R2 allowed the detection of barium sulphate with its principal signal at $986 \mathrm{~cm}^{-1}$ [49] (Fig. 11c).

The red pigment $\mathrm{R} 1$ analyzed using the $785 \mathrm{~nm}$ laser (Fig. 12a), revealed the presence of the principal signals of hematite $\left(\alpha-\mathrm{Fe}_{2} \mathrm{O}_{3}\right.$, main constituent of the red ochres) at $292,405,613 \mathrm{~cm}^{-1}$ [39]. Once again, a very intense luminescence band appeared in relation to earth-based pigments. It is centered at $1370 \mathrm{~cm}^{-1}$, corresponding to ca. $880 \mathrm{~nm}$, therefore the same consideration made in paragraph 3.1.2 can be done.

The brown sample spectrum in Fig. 12c, instead, is differentiated for the presence of a peak at $674 \mathrm{~cm}^{-1}$. This band is sometimes associated to hematite in peculiar conditions, for example it is related to structural disorder as a consequence of Al-for-Fe substitution [50] or due to hematite recrystallization with high temperature [51]. Notwithstanding, its presence as the only main peak apart those related to calcite, make magnetite $\left(\mathrm{Fe}_{3} \mathrm{O}_{4}\right)$ the most probable attribution $[39,52]$, which would account for the darker color of the area.

The Raman spectrum of the yellow pigment on YR sample displays peaks at 250,300, 390 and $558 \mathrm{~cm}^{-1}$ (Fig. 12b), attributed to the mineral goethite $(\alpha-\mathrm{FeOOH})$, one of the principal constituents of yellow ochres [39]. Both for goethite and for hematite, the main broad band centered at about 1310 and $1300 \mathrm{~cm}^{-1}$ respectively must 

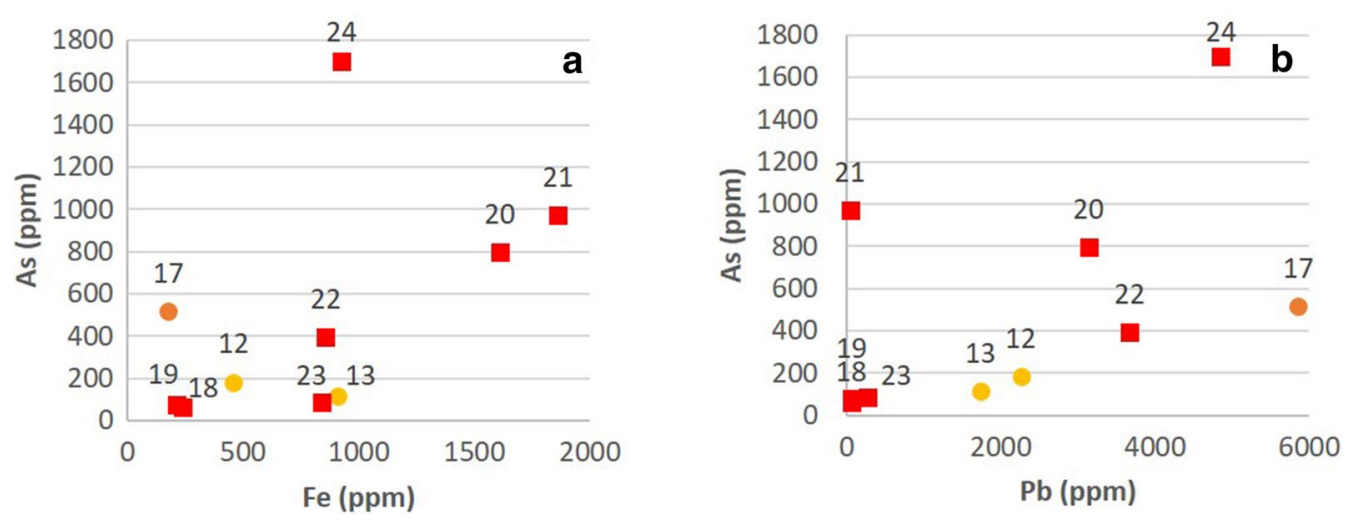

Fig. 7 Bivariate diagrams for yellow, orange and red areas: a As vs. Fe; b As vs. Pb. The color of the symbol corresponds to the analyzed shade. Squares indicate points on the vault and eastern wall and circles points on the North wall

Table 2 Summary of the vibrational spectroscopy signatures found for each analyzed color pigments, with respective attribution, figures and references

\begin{tabular}{|c|c|c|c|c|c|c|}
\hline Color & $\begin{array}{l}\text { Raman signature } \\
\left(\mathrm{cm}^{-1}\right)\end{array}$ & $\begin{array}{l}\text { ATR-FTIR } \\
\text { signature }\left(\mathrm{cm}^{-1}\right)\end{array}$ & DRIFT signature $\left(\mathrm{cm}^{-1}\right)$ & Attribution & & Refs \\
\hline \multirow[t]{2}{*}{ Blue } & 426,1080 & $\begin{array}{l}519,565,598,668,754 \\
906,1005,1047,1082 \\
1158\end{array}$ & $1006,1060,1250$ & Egyptian blue & $9 \mathrm{~d}, 11 \mathrm{a}, 13 \mathrm{~h} / \mathrm{h}^{\prime}, 13 \mathrm{i} / \mathrm{i}^{\prime}$ & {$[34,44,55,56]$} \\
\hline & 1006 & $\begin{array}{l}598,668,1111,1620 \\
3402,3527\end{array}$ & $1140,2120,2230$ & Gypsum & $9 e, 11 a, 13 \mathrm{i} / \mathrm{i}^{\prime}$ & {$[34,41,42,57]$} \\
\hline \multirow[t]{2}{*}{ Green } & - & 437,530 & $1065,1205,1550$ & Kaolinite, earths? & $9 \mathrm{~d}, 13 \mathrm{~g} / \mathrm{g}^{\prime}$ & {$[41,45,60,61]$} \\
\hline & & $668,1005,1165$ & & Egyptian blue? & & {$[55]$} \\
\hline Yellow & $250,300,390,558$ & $\begin{array}{c}470,539,798,910,1010 \\
1032,1083,1112,3622 \\
3648,3665,3690\end{array}$ & 3690,4524 & Yellow ochre & $9 b, 12 b, 13 f / f^{\prime}$ & {$[39,41,60,61]$} \\
\hline \multirow[t]{4}{*}{ Red } & 986 & $\begin{array}{l}606,630-640,984,1070 \\
\quad 1163\end{array}$ & & Baryte & $11 c, 13 \mathrm{~d} / \mathrm{d}^{\prime}, 13 \mathrm{e} / \mathrm{e}^{\prime}$ & [49] \\
\hline & & 680 & $1415,1740,2400$ & Cerussite & $13 \mathrm{e} / \mathrm{e}^{\prime}$ & {$[41,63]$} \\
\hline & & $\begin{array}{l}430,464,531,1009,1030 \\
\quad 1130,1182\end{array}$ & 1065,1109 & Red ochre & $10 \mathrm{~b}, 13 \mathrm{~d} / \mathrm{d}^{\prime}, 13 \mathrm{e} / \mathrm{e}^{\prime}$ & {$[39,41,44,60,61]$} \\
\hline & $228,292,405,613$ & & 1065,4525 & & $8 f, 10 c, 12 a$ & \\
\hline \multirow[t]{2}{*}{ Brown } & 674 & 466,565 & & Magnetite & $12 \mathrm{c}$ & {$[39,52,62]$} \\
\hline & & & $1030,1109,1550$ & Red ochre & $10 a, 13 c / c^{\prime}$ & {$[41,44]$} \\
\hline \multirow[t]{3}{*}{ White } & $158,282,714,1086$ & $\begin{array}{l}712,844,871,1085,1397 \\
2870\end{array}$ & $\begin{array}{l}880,1400,1795 \\
2515+2590,4270\end{array}$ & Calcite & $8 e, 9 c, 11 b, 13 b / b^{\prime}$ & {$[34,40-42,53,54]$} \\
\hline & 1006 & & & Gypsum & $11 b$ & {$[34]$} \\
\hline & 1050 & & & Cerussite & $11 b$ & {$[34]$} \\
\hline Black & 1375,1587 & & & Carbon black & $11 d$ & {$[48]$} \\
\hline
\end{tabular}

Numbers in bold: laboratory Raman analysis, in italics: in situ Raman analysis. Calcite signature was considered only for white

have been hidden by the very intense luminescence signal.

\section{Molecular spectroscopy-Fourier Transform Infrared- attenuated total reflectance}

In all the FTIR-ATR acquired spectra (Fig. 13, Table 2) the strong signals related to calcite are evident: it is clear that even though scraping a very small quantity of surface pigment, the carbonate substrate cannot be avoided and is present in the analyzed powder. Its signals are highlighted in Fig. 13 with red dotted lines and are positioned at $712\left(v_{4}\left(\mathrm{CO}_{3}\right)^{2-}\right), 844,871\left(v_{2}\left(\mathrm{CO}_{3}\right)^{2-}\right), 1085\left(v_{1}\right.$ $\left.\left(\mathrm{CO}_{3}\right)^{2-}\right)$ and $1397\left(\mathrm{v}_{3}\left(\mathrm{CO}_{3}\right)^{2-}\right) \mathrm{cm}^{-1}[53,54]$ and mainly characterize the spectrum of the white sample (Fig. 13b). 

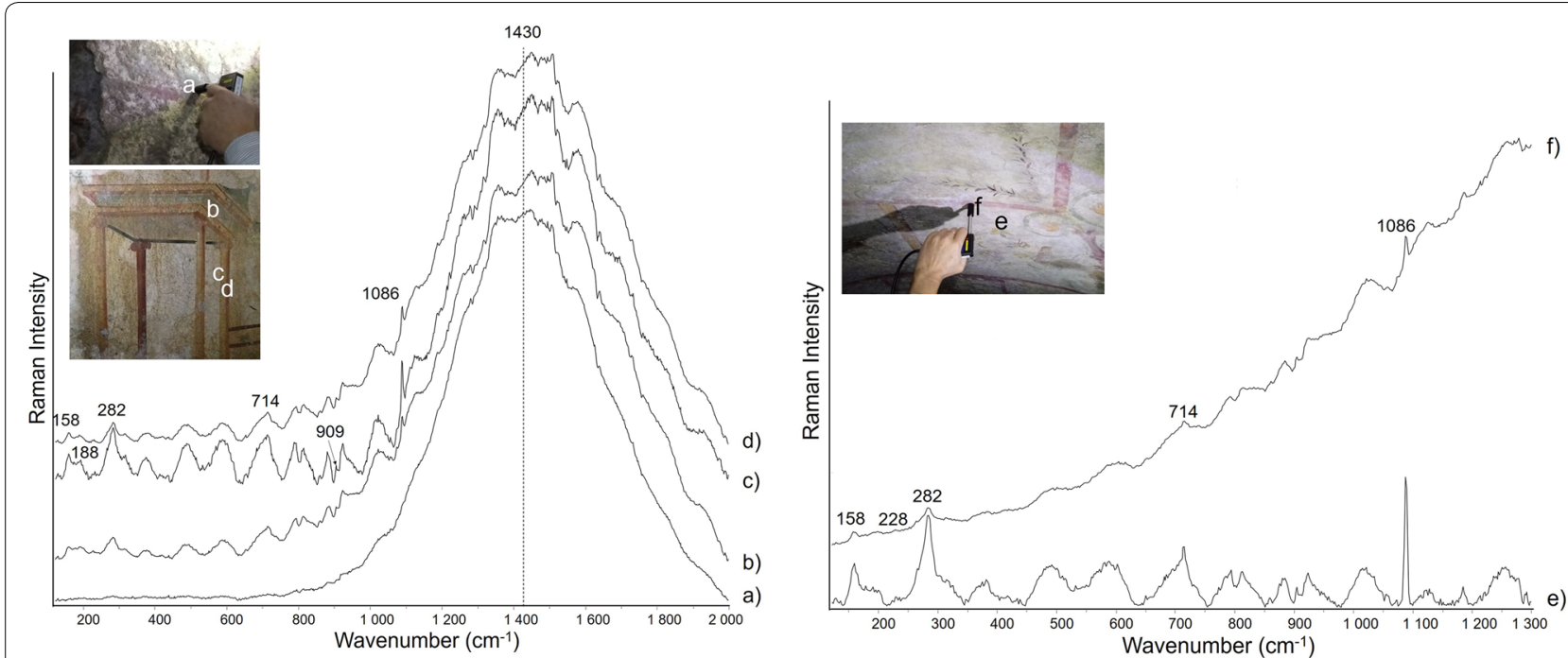

Fig. 8 Raman spectra acquired in situ and respective analyzed spots: a green, $\mathbf{b}$ green, c yellow, $\mathbf{d}$ orange, e white, $\mathbf{f}$ red. Dashed line: luminescence bands

A broad band between 900 and $1200 \mathrm{~cm}^{-1}$ is also visible in almost all the spectra, and it appears much lower in the carbon-based (see 3.2.1) black one (Fig. 13a). This band could be attributable to the presence of silicates, which are well-known to absorb in this region: they could be part of the pigments or be traces of dust/soil withstanding the delicate brush cleaning of the surface of the samples.

The ATR analyses confirm that the blue samples are constituted by Egyptian Blue (Fig. 13h), a silicate compound displaying bands in the region of asymmetrical Si-O-Si stretching, between 1000 and $1280 \mathrm{~cm}^{-1}$ [55]. For sample B1, its peaks (Table 2, [56]) overlap with those of gypsum (Table 2 [57]) in the spectra of Figs. 13i/i'. Furthermore, quartz is present, as its typical infrared absorbance doublet is visible in both spectra at 776 and $798 \mathrm{~cm}^{-1}$, together with the peak at $470 \mathrm{~cm}^{-1}$ [58].

Due to the extremely small size of the greyish sample (Fig. 3), the presence of green earths cannot be confirmed, as their principal peak centered between 950 and $970 \mathrm{~cm}^{-1}$ [59] could not be detected (Fig. 13g). Nevertheless, kaolinite, which is present in ochres and earths, is recognizable by the bands at 467 and $530 \mathrm{~cm}^{-1}[60,61]$, even if the spectrum-acquired on a too small quantity of powder-is too noisy to discern the typical signals in the high wavenumber region (Fig. 13g'). The signals at 668 , 1005 and $1165 \mathrm{~cm}^{-1}$ could suggest the addition of a small quantity of Egyptian Blue. Also, the presence of quartz is ascertained due to the presence of the above-mentioned doublet.

In the yellow (Figs. 13f/f') and red (Figs. 13d/d') samples, the spectra of ochres can be clearly recognized: the distinction between red and yellow ones could be tricky since their infrared spectra contain many similarities showing the same absorbance peaks due to kaolinite presence: outer hydroxyl ions around 3690, 3665 and $3650 \mathrm{~cm}^{-1}$ as well as inner hydroxyl ions at $3620 \mathrm{~cm}^{-1}[60]$ are present both in the yellow and in the red sample spectra (Fig. 13f' and e', respectively). Kaolinite also displays peaks at $479(\mathrm{Si}-\mathrm{O}), 536(\mathrm{Si}-\mathrm{O}-$ $\mathrm{Al}), 938$ and $914(\mathrm{Al}-\mathrm{O}-\mathrm{H}) 1009$ (Si-O-Al) and 1032 $(\mathrm{Si}-\mathrm{O}-\mathrm{Si}) \mathrm{cm}^{-1}[60,61]$. At the same time, according to [60] also the peaks of pure ferric oxide can be found between 400 and $750 \mathrm{~cm}^{-1}$, at 470 and $536 \mathrm{~cm}^{-1}$.

The brown sample, whose spectrum is shown in Fig. 13c/c', only exhibits two broad bands at 466 and $565 \mathrm{~cm}^{-1}$, the latter feature is consistent with the presence of magnetite [62].

The spectra in Fig. 13d and e, instead, were acquired on the same red fragment coming from the North wall (R2). Apart the already-mentioned ochre-based composition, both spectra show signals around 606 and $630-640,984,1070$ and $1163 \mathrm{~cm}^{-1}$, typical of a sulphate phase, in particular the positions fit best with barium sulphate $\left(\mathrm{Ba}_{2} \mathrm{SO}_{4}\right)$ [49]. Spectrum e) exhibits also an absorption band at about $680 \mathrm{~cm}^{-1}$, that, according to [63] is characteristic of lead white and helps its distinction from chalk. This could have been present in the mixture of pigments, or, according to [64], lead carbonate could have been formed on red lead based paints due to the interaction with an egg-based binding medium. Also, lead carbonate appears to be the most stable phase of $\mathrm{Pb}$-pigments degradation in atmospheric conditions [65]. 


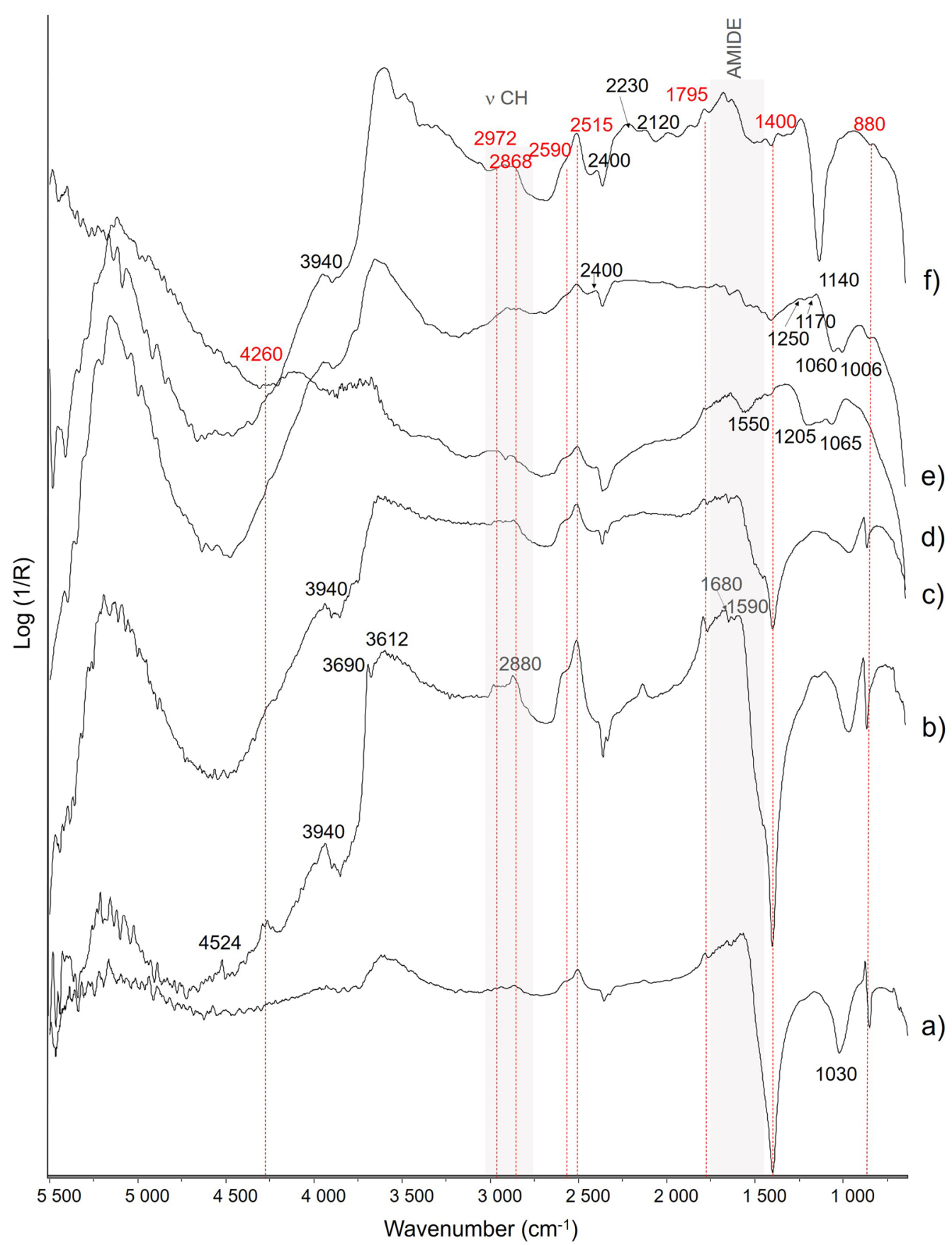

Fig. 9 DRIFT spectra of samples: a Frag2_BL, b Frag1_Y, c Frag1_W, d G, e B2, f B1. Red dotted lines and positions: calcite; grey areas: probable organic binder

The weak band at about $1650 \mathrm{~cm}^{-1}$, present also in the white and blue ones, falls in the amide I region of proteins $[64,66,67]$, on the other hand, the amide II region lacks its band at around $1540 \mathrm{~cm}^{-1}$, which could be included in the broadened and asymmetric band of carbonates (compare for example Fig. 13a and b). Looking at the high wavenumber region, indeed, the above-mentioned red (Fig. 13d', e') and white (Fig. 13b') samples' infrared spectra show a broadened calcite-related signal at $2870 \mathrm{~cm}^{-1}$, probably including a shoulder at $2850 \mathrm{~cm}^{-1}$, and peaks around 2920 and $3290 \mathrm{~cm}^{-1}$. These signals, though very weak, could be referred to the $\mathrm{CH}$ stretching [67]. There 


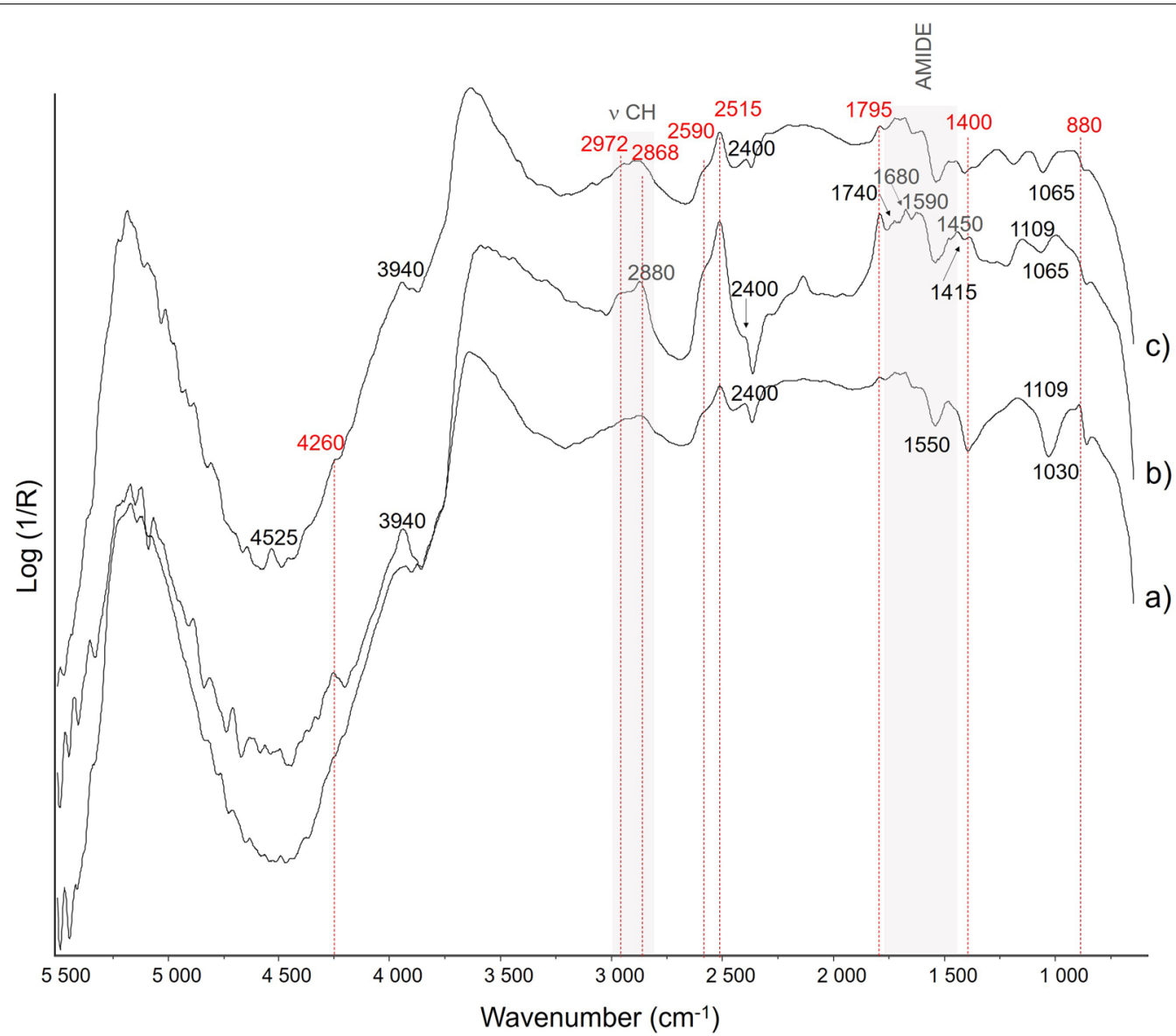

Fig. 10 DRIFT spectra of red samples: a BR, b R2; c Frag1_R. Red dotted lines and positions: calcite; grey areas: probable organic binder
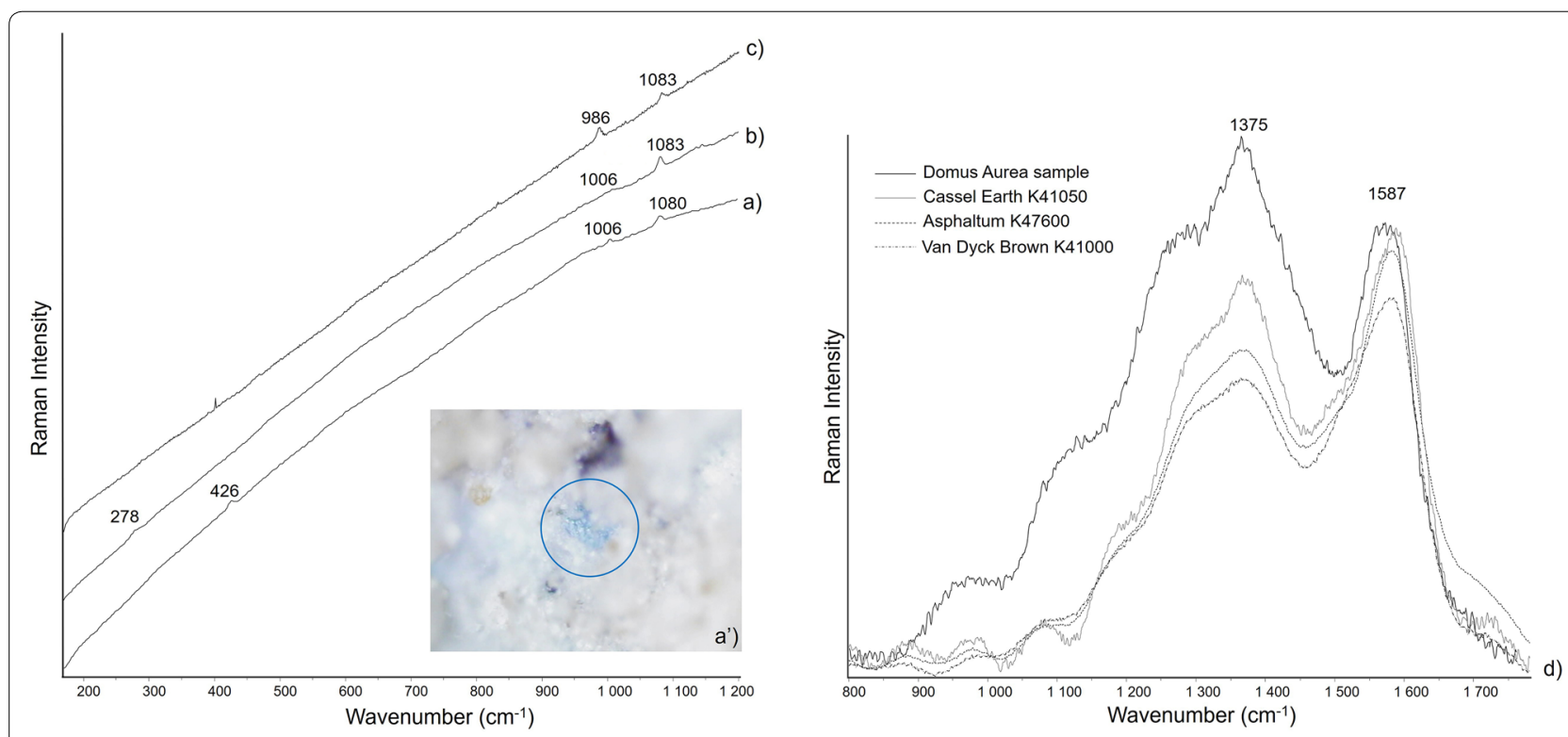

Fig. 11 Raman spectra acquired with the $532 \mathrm{~nm}$ laser on samples: a B1, with relative microscopic image $\left(\mathbf{a}^{\prime}\right)$, b W, $\mathbf{c}$ R2, d BL, with black reference pigments comparison 


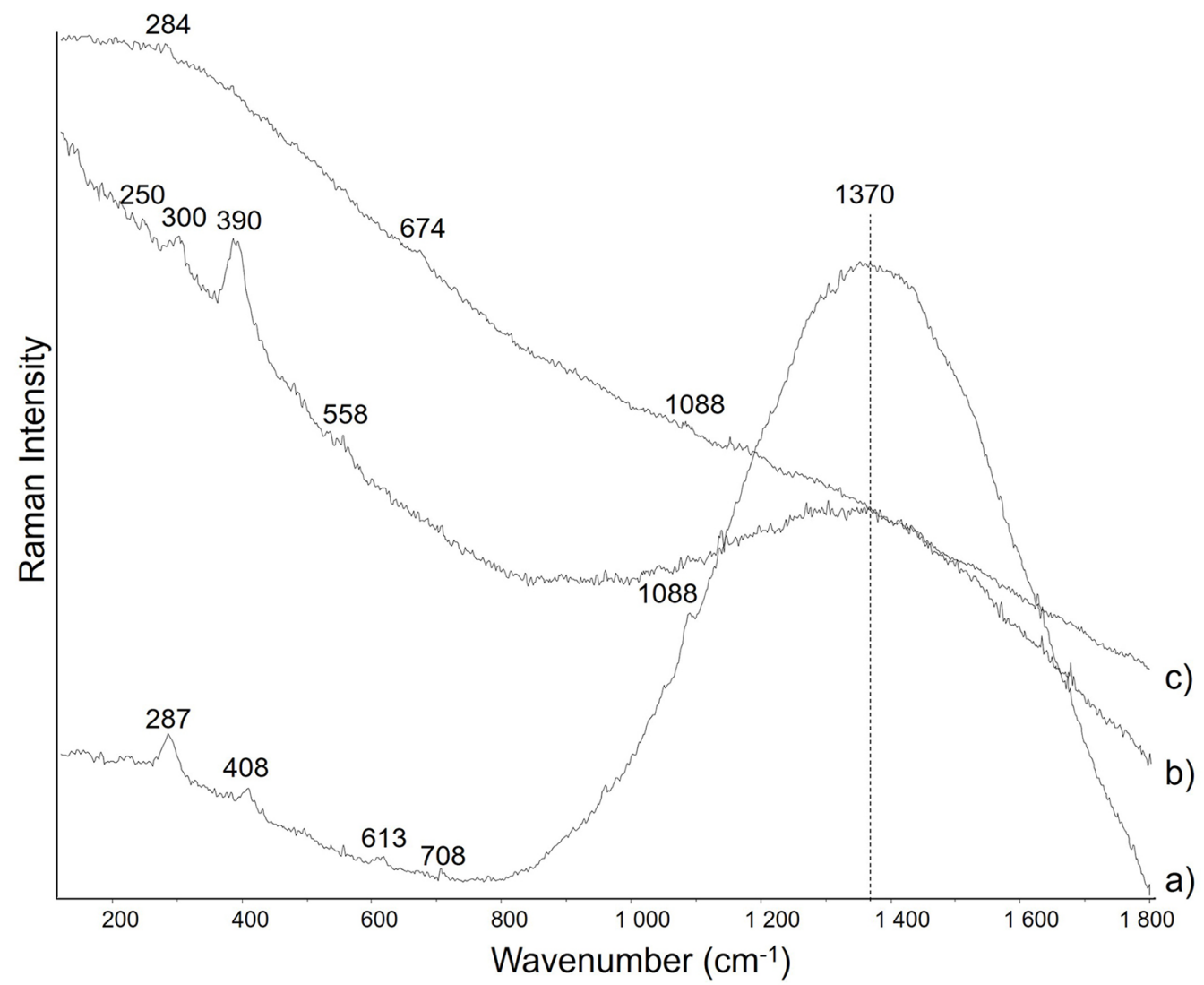

Fig. 12 Raman spectra acquired with the $785 \mathrm{~nm}$ laser on: a YR, b R1, c BR. Dashed line: luminescence band

is no trace of lipid-connected [64] or beeswax infrared absorbance bands [68].

\section{Discussion}

A summary of the results obtained with the different techniques employed can be found in Table 3. The consistency of the results and the respective integration of the elemental and molecular analyses is evident, as well as the good performance of the portable infrared analysis, comparable with the ATR laboratory one.

The ubiquitous presence of $\mathrm{Ca}$ and $\mathrm{K}$ (Fig. 5, Table 1) is most likely linked to the plaster composition, but it could also be indicative of the painting technique (fresco, mezzo fresco; use of soapy water [69]). The unambiguous confirmation of true fresco requires the assessment of the chemical binding of the pigment to the wall through cross-section observations $[10,70]$, on the other hand, the detection of organic binders is not straightforward, as discussed below [10]. On white spots the presence of calcite is clear, though Raman spectroscopy highlights also gypsum and lead white. The composition of the black pigment could be ascertained only thanks to laboratory
Raman analyses that revealed the use of a bituminous material.

A summary for the other colors' investigation is grouped according to the wall.

\section{South wall}

The Cu-based blue pigment found by means of pXRF (points 1 and 2) was confirmed as Egyptian blue by vibrational spectroscopies; the coexistence of gypsum on one of the analyzed fragments is also ascertained. $\mathrm{Fe}$ and $\mathrm{Cr}$ can be present as contaminants in the synthetic Egyptian blue pigment [23]; $\mathrm{Sn}$ is present in one point only, possibly indicating different manufacturing techniques [71, 72].

\section{Vault, East and West walls}

The dull greenish to bluish shades called "greyish" are mainly composed of earths, in which infrared spectroscopy identifies the presence of kaolinite, which in green earths is found together with celadonite or glauconite, nevertheless, not all the characteristic signals could be detected. On the other hand, the presence of Egyptian Blue in the mixture can be suggested. PXRF shows a 

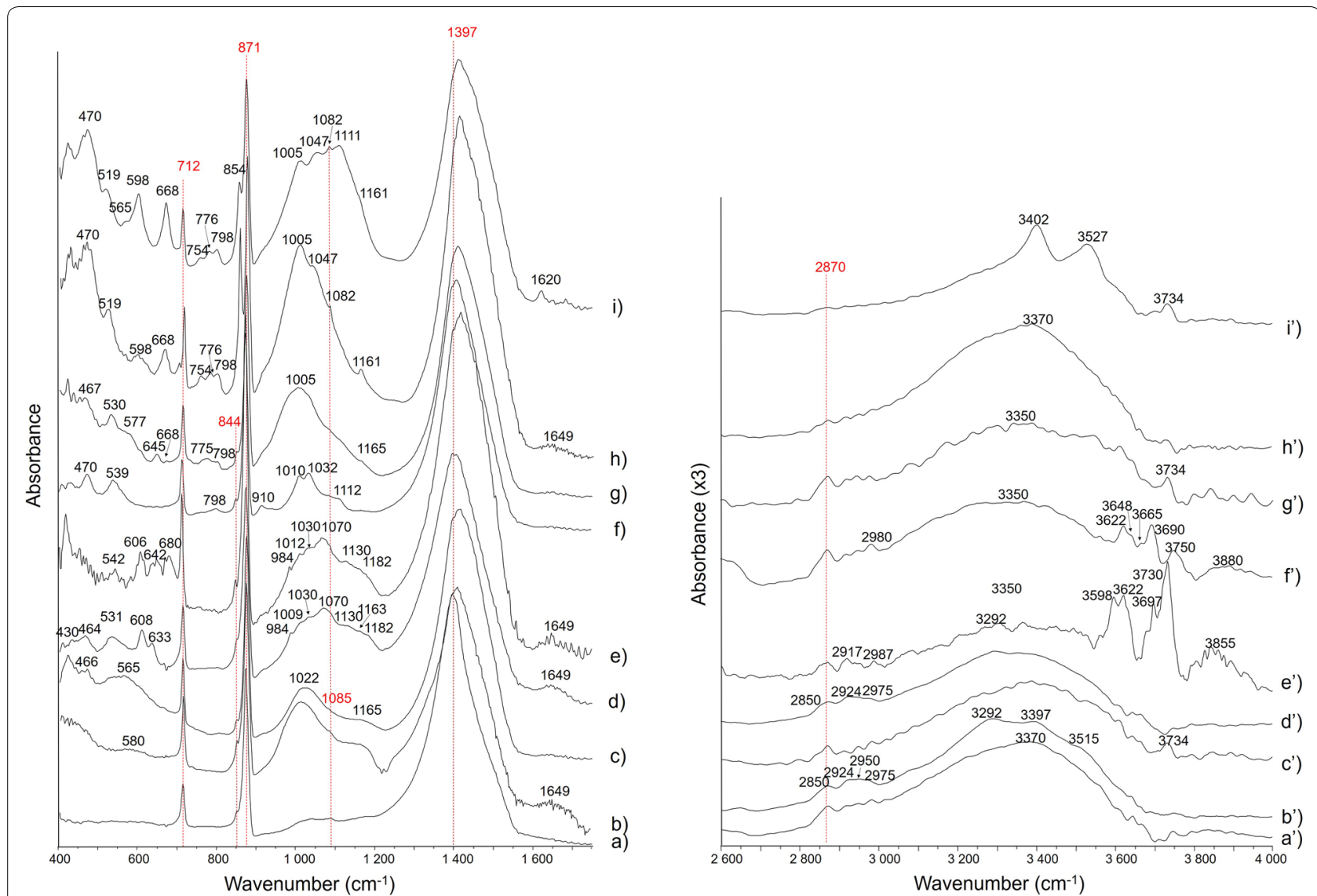

Fig. 13 FTIR-ATR absorbance spectra (ranges 400-1750 and 2600-4000 $\left.\mathrm{cm}^{-1}\right)$ of samples: $\left(\mathbf{a} / \mathbf{a}^{\prime}\right) B L,\left(\mathbf{b} / \mathbf{b}^{\prime}\right) W,\left(\mathbf{c} / \mathbf{c}^{\prime}\right) B R,\left(\mathbf{d} / \mathbf{d}^{\prime}\right)\left(\mathbf{e} / \mathbf{e}^{\prime}\right) R 2,\left(\mathbf{f} / \mathbf{f}^{\prime}\right) Y,\left(\mathbf{g} / \mathbf{g}^{\prime}\right)$ $\mathrm{G},\left(\mathbf{h} / \mathbf{h}^{\prime}\right) B 2,\left(\mathbf{i} / \mathbf{i}^{\prime}\right)$ B1. For the high-wavenumber range, the absorbance values were magnified X3. Red dotted lines and positions: calcite

positive trend between $\mathrm{K}$ and Fe (Fig. $6 \mathrm{~b}$ ), supporting the presence of green earths. Moreover, the presence of $\mathrm{Cr}$ in association with $\mathrm{Fe}$ in all the measured points (Table 1) suggests the use of Cr-rich green earths, such as, for example, celadonite from Verona [73], which was well known to Romans [1].

The greyish point 10 , with the highest $\mathrm{Cu}$ content from pXRF in situ analyses, could not be analyzed through molecular techniques. This greyish-blue swirl of the vault's central decoration can be interpreted as a mixture of Egyptian blue $(\mathrm{Cu})$, lead white $(\mathrm{Pb})$, and green earths $(\mathrm{K}, \mathrm{Fe}, \mathrm{Cr})$. The use of such a complex mixture is not surprising [23, 73].

The yellow and red colors' elemental composition seems to be based either on $\mathrm{Fe}$ or on $\mathrm{Fe}+\mathrm{Pb}$, with $\mathrm{Fe}$ clearly associated with K (Fig. 6). The presence of iron compounds is unanimously confirmed by vibrational spectroscopies, that identify ochres (iron oxides and hydroxides in aluminosilicate matrix). The yellow of the vault is Fe-based, confirmed as yellow ochre by vibrational techniques. For red, it appears that Pb-only red was used on the vault only, while the walls show mixtures with Fe-pigments, or the latter alone. Red ochres show consistently an enrichment in As, which is very low or absent in the yellows (Fig. 7d) [74, 75]. This suggests that red ochres were directly sourced, and not obtained by heating yellow ochres. The $\mathrm{Pb}$-rich reds of the vault (points 20,22, 24) also show an enrichment in As: this element is commonly present in lead ores and in ironrich soils, and was ascertained in Pompeian Fe-rich red hues [75] and in Tarquinia tombs [16].

\section{North wall}

The pXRF analyses on this wall consistently show an enrichment in barium (Table 1, Fig. 5), whose origin is not clear. Either a different raw material could have been used for the plaster of this wall $[69,76]$, or it could be a result of localized environmental contamination from percolation. Barium salts were nevertheless confirmed by means of FTIR-ATR on fragments, and could result from biological activity on a Ba-rich substrate [77].

It has to be noted that the North wall's reds analyzed in situ by means of pXRF (points 18 and 19, Fig. 4) show very low $\mathrm{Pb}$ and $\mathrm{Fe}$ counts: the yellowish-brown patina 
Table 3 Summary of the results achieved with the different techniques

\begin{tabular}{|c|c|c|c|c|c|c|c|}
\hline \multirow[t]{2}{*}{ Color } & \multicolumn{3}{|l|}{ In situ } & \multicolumn{4}{|l|}{ Fragments } \\
\hline & Wall (points) & pXRF & Raman & $\begin{array}{l}\text { Sample Code } \\
\text { (wall) }\end{array}$ & Raman & DRIFT & ATR \\
\hline \multirow[t]{3}{*}{ Blue } & $S(1,2)$ & Cu-rich & & B1 (S) & Egyptian Blue + Gyp & ssum & \\
\hline & & & & & & Organic binder? & \\
\hline & & & & B2 (S) & Egyptian Blue & & \\
\hline \multirow[t]{3}{*}{ Greyish } & N, Vault (3-8) & Fe-K rich & Weddellite & $\mathrm{G}$ (Vault) & & Kaolinite (Earths?) & \\
\hline & & & & & & & Egyptian Blue? \\
\hline & Vault $(9,10)$ & $\begin{array}{l}\text { Cu-rich, Fe-K rich, } \\
\mathrm{Pb}\end{array}$ & & & & & \\
\hline \multirow[t]{4}{*}{ Yellow } & E, W, Vault (14-16) & Fe-rich & & $\begin{array}{l}\text { Y, YR (Vault / S-W } \\
\text { corner) }\end{array}$ & Yellow ochre & Organic binder? & \\
\hline & & & & Frag1_Y (Vault) & & Yellow ochre & \\
\hline & $N(11)$ & patina & Weddellite & & & & \\
\hline & $N(12,13)$ & Pb-rich & & & & & \\
\hline Orange & $N(17)$ & Pb-rich & & & & & \\
\hline \multirow[t]{6}{*}{ Red } & E, W, Vault (20-24) & Fe-rich; \pm Pb-rich & $\begin{array}{l}\text { Red ochre (Hema- } \\
\text { tite) }\end{array}$ & R1 (Vault) & Red ochre (Hematite & & \\
\hline & & & & $\begin{array}{l}\text { YR (Vault / S-W } \\
\text { corner) }\end{array}$ & $\begin{array}{l}\text { Red ochre (Hema- } \\
\text { tite) }\end{array}$ & & \\
\hline & & & & Frag1_R (Vault) & & $\begin{array}{l}\text { Red ochre (Hema- } \\
\text { tite) }\end{array}$ & \\
\hline & $N(18,19)$ & patina: no Pb, & & $\mathrm{R} 2(\mathrm{~N})$ & Red ochre (Hematite & & \\
\hline & & low Fe & & & & Pb-based compound & \\
\hline & & & & & & Organic binder & \\
\hline \multirow[t]{2}{*}{ Brown } & & & & $\begin{array}{l}\text { BR (Vault / S-W } \\
\text { corner) }\end{array}$ & & $\begin{array}{l}\text { Red ochre (Hema- } \\
\text { tite) }\end{array}$ & \\
\hline & & & & & Magnetite & & Magnetite \\
\hline \multirow[t]{3}{*}{ White } & $\mathrm{N}, \mathrm{E}$, Vault & & Calcite & Frag1_W (Vault) & & Calcite & \\
\hline & & & & $W(W)$ & Calcite + Gypsum & Calcite & \\
\hline & & & & & & Organic binder & \\
\hline Black & & & & $\mathrm{BL}(\mathrm{S})$ & Carbon & & \\
\hline
\end{tabular}

in the area of the temple (Fig. 4b) could have negatively affected the pXRF results. Interestingly, the fragment coming from the North wall (R2) shows, thanks to infrared spectroscopy, traces of a Pb-based pigment, while the brown one (BR) displays, through Raman and ATR investigations, the signals of magnetite.

Yellows are both Fe and $\mathrm{Pb}$-based, respectively measured on the architectural detail (point 11, Fig. 4) and on the Sphinx (points 12 and 13, Fig. 4). The lead presence in yellows does not correspond in the vibrational spectra, probably due to the very few samples that could be brought to the laboratory and to the difficulties of obtaining Raman spectra in situ. It seems worth to note that these two Pb-yellows and orange (points 12 and 13, Fig. 4), both belonging to the Sphinx, show the signal of lead, as well as of As, possibly indicating the use of a lead ore with mimetite $\left(\mathrm{Pb}_{5}\left(\mathrm{AsO}_{4}\right)_{3} \mathrm{Cl}\right)$ [78]. Pb-orange has remarkable $\mathrm{Sn}$, which has been highlighted as a possible marker for red lead as a by-product of Spanish silver smelting activities [79].

The absence of a diffuse usage of copper-based green and cinnabar, both distinguishing the more refined paintings of Room 119 [7], and the latter characterizing, together with madder lake, the Gilded Vault [24] mark the difference between the decorations of the Sphinx Room and those of other spaces of Domus Aurea.

The general palette found for the Sphinx Room seems instead comparable to that of Corridor 92 [7] and of Room 114 (Sala delle Maschere [23]). In both cases, indeed, the palette mainly consisted of the same common pigments. Nevertheless, the skillful use of the pigments allowed the painter to obtain a wide variety of shades. Such a palette has been moreover identified in the city landscape painting (identified as Arles, France) in Trajan's bath criptoportico [69], in some rooms of the Case Romane complex, [56, 80], as well as in the Augustan 
epoch garden from the suburban villa in the Lateran palimpsest [26].

With regard to the employed painting technique, the finding of hints recalling to a proteinaceous substance in some of the samples studied with the laboratory instrumentation (blue, yellow, red and white, especially evident for the latter two) could suggest the use of an organic binder, at least to trace some specific details [80]. This presence would also explain the high fluorescence observed in the Raman spectra also with laboratory instrumentation. However, this subject requires a deeper investigation, since the predominance of calcite in the great part of both DRIFT and ATR spectra hindered an irrefutable attribution of the weak signals. Furthermore, due to the presence on the painted walls of an extensive biological attack, it cannot be excluded that this material revelation is due to the microbial biomass [81]. The use of the fresco technique for the great part of the paintings cannot be excluded, also considering the presence of incisions useful to set out the composition, which, according to [7] would suggest that the pigment was applied to fresh lime plaster. Furthermore, the traces of brushstrokes, typical when paint is applied $a$ secco, can be observed in some details, such as the tuft and the fruitfilled branches on the vault and the temple on the North wall (Additional file 2: SM2b).

\section{Conclusions}

This work leads to relevant conclusions both on the methodological and on the archaeological point of view on the analysis of Roman wall paintings, both in situ and on fragments in the lab.

Concerning the former, the integrated analytical approach proved successful for the identification of the full range of pigments used. This allowed at the same time a preliminary comprehensive view of the mural paintings composition and successive in-depth investigation, exploiting the advantages of each technique. Notwithstanding the advantages of pXRF in terms of fast, multielement analyses, the need for a complementary molecular analysis appears evident in this field of study, as many pigments share the same key elements. Moreover, Raman spectroscopy could overcome the problems of infrared spectroscopy in the analysis of black pigments, whereas the latter helped in the detection of organic substances probably generating fluorescence in the Raman spectra. The portable infrared technique working in reflectance (DRIFT) gave satisfactory results, generally comparable with those obtained with laboratory FTIR-ATR, encouraging towards its usage, better if in atmospheric conditions with a low degree of relative humidity. As a whole, the analytical methodology employed proved efficient and effective to overcome the logistic and analytical difficulties.

From the archaeological point of view, the color palette emerging from the results (Egyptian blue, green earths, iron- and lead-based red, orange and yellow, lead white, calcite, carbon black) allows to compare the Sphinx Room to other Domus Aurea's spaces such as Corridor 92 and Room 114, to Trajan's bath "criptoportico" on the same hill, and to some rooms of the Case Romane complex on the Caelian hill, that are decorated with a less refined style and with commonly used pigments. The absence of precious pigments, such as cinnabar and $\mathrm{Cu}$-based green pigments, and of precious metals such as gold, which were nevertheless identified in other rooms of the Domus Aurea, suggest that this room was not intended for representative purposes.

A differentiation of the palette according to the wall does not seem to follow an intentional choice. The only $\mathrm{Cu}$-based greyish on the vault being a dull blue color made of a mixture of Egyptian blue, green earths and lead white. The only difference could be recognized in the $\mathrm{Pb}$-based yellow pigments that were found on the North wall only, namely in the Sphinx and temple, whereas this distinction is not as much clear for the red tones.

For the first time, an attempt at identifying the painting technique was carried out in the Domus Aurea, leading to highlight traces of an organic binder. Notwithstanding, due to the few fragments that could be analyzed, a more extensive employ of the fresco technique, with only some specific points painted a secco, cannot be excluded.

\section{Supplementary information}

Supplementary information accompanies this paper at https://doi. org/10.1186/s40494-020-00465-1.

Additional file 1. Sections of the Sphinx Room: a) Vault, horizontal section b) East wall, A-A' section, c) West wall, A'-A section, d) North wall, B-B' section, e) South wall, $C^{\prime}-C$ section (See Figure 1 for reference). Credits: A. Blanco, D. Nepi, F. Vozzolo. Copyright: PArCo.

Additional file 2. Raking light detail images of a) the incisions used to set out the composition of the frame between the vault and the East wall, b) the brushstrokes visible on the temple on North wall.

\section{Acknowledgements}

The authors thank Dr. Maria Bartoli, restorer of the PArCo, and all the Domus Aurea staff, and particularly Architect Stefano Borghini, technical manager, Dr. Elisabetta Segala, archaeologist, Landscape Architect Gabriella Strano, and Surveyor Maurizio Pesce, technology official. Dr. Giulia Giovanetti, archaeologist, is thanked for fruitful discussions. The authors are also grateful to Davide Manzini, Madatec Srl, for the usage of portable DRIFTS instrumentation. This work is supported by found of the "programma ricerca di ateneo UNICT 202022 linea 2" of the Department of Biological, Geological and Environmental Sciences, University of Catania. 


\section{Authors' contributions}

Conceptualization: GB, AD, PM; Methodology: GB, MCC, AC, PM; Formal analysis and investigation: $G B, M C C, A C, P M ;$ Writing —original draft preparation: MCC, AC, AD; Funding acquisition: GB, PM; Supervision: AR. All authors read and approved the final manuscript.

\section{Funding}

This work is supported by funds of the "programma ricerca di ateneo UNICT 2020-22 linea 2" of the Department of Biological, Geological and Environmental Sciences, University of Catania.

\section{Availability of data and materials}

All data generated or analyzed during this study are included in this published article and its supplementary information files.

\section{Competing interests}

The authors declare that they have no competing interests.

\section{Author details}

${ }^{1}$ Department of Biological, Geological and Environmental Sciences, University of Catania, Catania, Italy. ${ }^{2}$ Parco Archeologico del Colosseo, Rome, Italy.

Received: 15 July 2020 Accepted: 11 November 2020

Published online: 28 November 2020

\section{References}

1. Pliny the Elder. The Natural History. Bostock PD, Riley HT, editors. London: Taylor and Francis; 1855.

2. Ball LF. The Domus Aurea and the Roman architectural revolution. Cambridge: Cambridge University Press; 2003. p 307. https://books.google.be/ books?hl=en\&lr=\&id=kZogAwAAQBAJ\&oi=fnd\&pg=PT11\&dq=The+D omus+Aurea+and+the+Roman+Architectural+Revolution\&ots=FFeB DYJpNG\&sig=_iQsk7dbcGCbNw4FGns5tuj4Ka.

3. La Malfa C. The Chapel of San Girolamo in Santa Maria del Popolo in Rome. New Evidence for the Discovery of the Domus Aurea. J Warburg Courtauld Inst. 2000;63:259-70.

4. Anderson JC. The Date of the Thermae Traiani and the Topography of the Oppius Mons. Am J Archaeol. 1985;89(3):499-509.

5. García JT. Classical Tradition and the Painting of Giovanni da Udine Classical Tradition and the Painting of Giovanni da Udine. RES Antiq. 2019;1:14-28.

6. Moormann EM. Roman wall painting. In: Encyclopedia of Global Archaeology. Berlin: Springer; 2018. p. 1-22.

7. Payne E, Booms D. Analysis of pigment palettes as evidence for room status in Nero's Golden House. Tech Res Bull. 2014;8:117-26.

8. Siddall R. Not a day without a line drawn: pigments and painting techniques of Roman Artists. Focus Mag Proc R Microsc Soc. 2006;2:18-31.

9. Davy HVIII. Some experiments and observations on the colours used in painting by the ancients. Philos Mag. 1815;45(206):414-22.

10. Cuní J. What do we know of Roman wall painting technique? Potential confounding factors in ancient paint media analysis. Herit Sci. 2016;4(1):1-13.

11. Birolo L, Tomeo A, Trifuoggi M, Auriemma F, Paduano L, Amoresano A, et al. A hypothesis on different technological solutions for outdoor and indoor Roman wall paintings. Archaeol Anthropol Sci. 2017;9(4):591-602.

12. Baraldi P, Baraldi C, Curina R, Tassi L, Zannini P. A micro-Raman archaeometric approach to Roman wall paintings. Vib Spectrosc. 2007;43(2):420-6.

13. De Vos M. La bottega di pittori di via Castricio. In: POMPEI 1748-1980 I tempi della documentazione. Rome: Multigrafica Editrice; 1981.

14. Mazzocchin GA, Agnoli F, Mazzocchin S, Colpo I. Analysis of pigments from Roman wall paintings found in Vicenza. Talanta. 2003;61(4):565-72.

15. Mazzocchin GA, Orsega EF, Baraldi P, Zannini P. Aragonite in Roman Wall Paintings of the VIII ${ }^{\mathrm{a}}$ Regio, Aemilia, and Xa Regio. Venetia et Histria Ann Chim. 2006;96:377-87.

16. Barone G, Mazzoleni P, Cecchini A, Russo A. In situ Raman and pXRF spectroscopic study on the wall paintings of Etruscan Tarquinia tombs. Dye Pigment. 2018;150:390-403. https://doi.org/10.1016/j.dyepig.2017.12.008.
17. Artioli G, Angelini I, editors. Scientific methods and cultural heritage: an introduction to the application of materials science to archaeometry and conservation science. Oxford: Oxford University Press; 2010. https://books.google.be/books?hl=en\&lr=\&id=HsQUDAAAQBAJ\&oi=f$n d \& p g=P R 11 \& d q=x r d+$ archaeometry+review\&ots=uyjPikEd19\&sig $=x X-i D V J 8 v r 4 t X 2 z R y a D e w 5 P y F 8 s \# v=$ onepage $\& q=x r d$ archaeometry review\&f $=$ false

18. Bersani D, Lottici PP. Raman spectroscopy of minerals and mineral pigments in archaeometry. J Raman Spectrosc. 2016;47(5):499-530. https:// doi.org/10.1002/jrs.4914/full.

19. Janssens K, Van Grieken R, editors. Non-destructive microanalysis of cultural heritage materials. New York: Elsevier; 2004. https://books.google.be/books?hl=en\&lr=\&id=zzqxUOOgNp $4 C \& o i=f n d \& p g=P R 1 \& d q=$ janssens + van + grieken\&ots $=91 \mathrm{aWyVhBuH}$ $\&$ sig=j9SUO5_Y9z-sX5AAhRv4sVRX221.

20. Seccaroni C, Moioli P, Luchinat Acidini C. Fluorescenza X: prontuario per I'analisi XRF portatile applicata a superfici policrome. Nardini Editore; 2002. p 161. https://www.bcin.ca/bcin/detail.app?id=200013.

21. Uda M, Demortier G, Nakai I, editors. X-rays for Archaeology. X-rays for Archaeology. Dordrecht: Springer; 2005. p 308.

22. Vandenabeele P, Donais MK. Mobile spectroscopic instrumentation in archaeometry research. Appl Spectrosc. 2016;70(1):27-41.

23. Paradisi A, Sodo A, Artioli D, Botti A, Cavezzali D, Giovagnoli A, et al. Domus aurea, the "Sala delle maschere": chemical and spectroscopic investigations on the fresco paintings. Archaeometry. 2012;54(6):1060-75.

24. Clementi C, Ciocan V, Vagnini M, Doherty B, Tabasso ML, Conti C, et al. Non-invasive and micro-destructive investigation of the Domus Aurea wall painting decorations. Anal Bioanal Chem. 2011;401(6):1815-26.

25. Bearat $\mathrm{H}$, editor. Proceedings of the International Workshop on Roman Wall Painting. Fribourg: Suisse; 1997.

26. Coccato A, Mazzoleni P, Spinola G, Barone G. (submitted) Two centuries of painted plasters from the Lateran suburban villa (Rome): investigating supply routes and manufacturing of pigments. J Cult Herit. 2020;

27. Albertano P, Luongo L, Grilli CM. Influence of different lights of mixed cultures of microalgae from ancient frescoes. Int Biodeterior. 1991;27(1):27-38

28. Giavarini C. Domus Aurea: the conservation project. J Cult Herit. 2001;2(3):217-28

29. Albero S, Giavarini C, Santarelli ML, Vodret A. CFD modeling for the conservation of the Gilded Vault Hall in the Domus Aurea. J Cult Herit. 2004;5(2):197-203.

30. Barone PM, Mattei E, Lauro SE, Pettinelli E. Non-destructive technique to investigate an archaeological structure: a GPR survey in the Domus Aurea (Rome, Italy). Proceeding of 13th International Conference Gr Penetrating Radar, GPR 2010. 2010. pp 1-4.

31. Meyboom PGP, Moormann EM. Le decorazioni dipinte e marmoree della Domus Aurea di Nerone a Roma (Vol. I: Testo; Vol. II: Illustrazioni). Leuven: Peeters; 2013. https://repository.ubn.ru.nl/handle/2066/105729.

32. Andreoli M. Mosaics of frescoes: digital photogrammetry, raster representation, pigment analysis and metrology of a Flavian wall painting on the Caelian Hill (Rome). Cambridge Archaeol J. 2014;24(2):233-47.

33. Solé VA, Papillon E, Cotte M, Walter P, Susini J. A multiplatform code for the analysis of energy-dispersive X-ray fluorescence spectra. Spectrochim Acta Part B At Spectrosc. 2007;62(1):63-8.

34. Bell IM, Clark RJH, Gibbs PJ. Raman spectroscopic library of natural and synthetic pigments (pre- $\approx 1850$ AD). Spectrochim Acta Part A Mol Biomol Spectrosc. 1997;53(12):2159-79. https://doi.org/10.1016/S1386 -1425(97)00140-6.

35. MacRae CM, Wilson NC. Luminescence database I-minerals and materials. Microsc Microanal. 2008;14(2):184-204.

36. Frost RL, Weier ML. Raman spectroscopy of natural oxalates at 298 and 77 K. J Raman Spectrosc. 2003;34(10):776-85. https://doi.org/10.1002/ jrs.1052.

37. Cariati F, Rampazzi L, Toniolo L, Pozzi A. Calcium oxalate films on stone surfaces: experimental assessment of the chemical formation. Stud Conserv. 2000;3:180-8.

38. Rampazzi L. Calcium oxalate films on works of art: a review. J Cult Herit. 2019;40:195-214. https://doi.org/10.1016/j.culher.2019.03.002.

39. Froment F, Tournié A, Colomban P. Raman identification of natural red to yellow pigments: Ochre and iron-containing ores. J Raman Spectrosc. 2008;39(5):560-8. https://doi.org/10.1002/jrs.1858. 
40. Arrizabalaga I, Gómez-Laserna O, Carrero JA, Bustamante J, Rodríguez A, Arana G, et al. Diffuse reflectance FTIR database for the interpretation of the spectra obtained with a handheld device on built heritage materials. Anal Methods. 2015;7(3):1061-70.

41. Miliani C, Rosi F, Daveri A, Brunetti BG. Reflection infrared spectroscopy for the non-invasive in situ study of artists' pigments. Appl Phys A Mater Sci Process. 2012;106(2):295-307.

42. Nodari L, Ricciardi P. Non-invasive identification of paint binders in illuminated manuscripts by ER-FTIR spectroscopy: a systematic study of the influence of different pigments on the binders' characteristic spectral features. Herit Sci. 2019;7(1):1-13. https://doi.org/10.1186/s4049 4-019-0249-y.

43. Piqué F, Verri G, editors. Organic materials in wall paintings. Getty Conservation Institute; 2015. https://courtauld.pure.elsevier.com/en/publicatio ns/iorganic-materials-in-wall-paintingsi

44. Manfredi M, Barberis E, Aceto M, Marengo E. Non-invasive characterization of colorants by portable diffuse reflectance infrared Fourier transform (DRIFT) spectroscopy and chemometrics. Spectrochim Acta Part A Mol Biomol Spectrosc. 2017;181:171-9. https://doi.org/10.1016/j. saa.2017.03.039.

45. Izzo F, Germinario C, Grifa C, Langella A, Mercurio M. External reflectance FTIR dataset (4000-400 cm - 1) for the identification of relevant mineralogical phases forming Cultural Heritage materials. Infrared Phys Technol. 2020. https://doi.org/10.1016/j.infrared.2020.103266.

46. Rosi F, Daveri A, Miliani C, Verri G, Benedetti P, Piqué F, et al. Non-invasive identification of organic materials in wall paintings by fiber optic reflectance infrared spectroscopy: a statistical multivariate approach. Anal Bioanal Chem. 2009;395(7):2097-106.

47. Caggiani MC, Cosentino A, Mangone A. Pigments Checker version 3.0 a handy set for conservation scientists: a free online Raman spectra database. Microchem J. 2016;129:123-32. https://doi.org/10.1016/j.micro c.2016.06.020

48. Coccato A, Jehlicka J, Moens L, Vandenabeele P. Raman spectroscopy for the investigation of carbon-based black pigments. J Raman Spectrosc 2015;46(10):1003-15.

49. Baryte R040036. https://rruff.info/repository/sample_child_record_infra red/by_minerals/Baryte_R040036-1__nfrared_Infrared_Data_Proce ssed_220.txt.

50. Zoppi A, Lofrumento C, Castellucci EM, Sciau P. Al-for-Fe substitution in hematite: the effect of low Al concentrations in the Raman spectrum of Fe2O3. J Raman Spectrosc. 2008;39(1):40-6. https://doi.org/10.1002/ jrs.1811.

51. Leon Y, Lofrumento C, Zoppi A, Carles R, Castellucci EM, Sciau P. Micro-Raman investigation of terra sigillata slips: a comparative study ofcentral Italian and southern Gaul productions. J Raman Spectrosc. 2010;41(11):1550-5.

52. de Faria DLA, Venâncio Silva S, de Oliveira MT. Raman microspectroscopy of some iron oxides and oxyhydroxides. J Raman Spectrosc. 1997;28(11):873-8. https://doi.org/10.1002/\%28SICl\%29109 7-4555\%28199711\%2928\%3A11\%3C873\%3A\%3AAID-JRS17 7\%3E3.0.CO\%3B2-B.

53. Gunasekaran S, Anbalagan G, Pandi S. Raman and infrared spectra of carbonates of calcite structure. J Raman Spectrosc. 2006;37:892. https:// doi.org/10.1002/jrs.1518/full.

54. Calcite R040070. https://rruff.info/repository/sample_child_record_infra red/by_minerals/Calcite_R040070-1_Infrared_Infrared_Data_Proce ssed_224.txt.

55. Bruni S, Cariati F, Casadio F, Toniolo L. Spectrochemical characterization by micro-FTIR spectroscopy of blue pigments in different polychrome works of art. Vib Spectrosc. 1999;20:15-25.

56. Fermo P, Piazzalunga A, De Vos M, Andreoli M. A multi-analytical approach for the study of the pigments used in the wall paintings from a building complex on the Caelian Hill (Rome). Appl Phys A Mater Sci Process. 2013;113(4):1109-19.

57. Gypsum R040029. https://rruff.info/repository/sample_child_record_infra red/by_minerals/Gypsum_R040029-1_Infrared_Infrared_Data_Proce ssed_291.txt.

58. Quartz R040031. https://rruff.info/repository/sample_child_record_infra red/by_minerals/Quartz_R040031-1_Infrared_Infrared_Data_Proce ssed_348.txt.
59. Ospitali F, Bersani D, Di Lonardo G, Lottici PP. 'Green earths': vibrational and elemental characterization of glauconites, celadonites and historical pigments. J Raman Spectrosc. 2008;39(8):1066-73. https://doi. org/10.1002/jrs. 1983.

60. Bikiaris D, Daniilia S, Sotiropoulou S, Katsimbiri O, Pavlidou E, Moutsatsou AP, et al. Ochre-differentiation through micro-Raman and microFTIR spectroscopies: application on wall paintings at Meteora and Mount Athos, Greece. Spectrochim Acta Part A Mol Biomol Spectrosc. 2000:56(1):3-18.

61. Vahur S, Teearu A, Leito I. ATR-FT-IR spectroscopy in the region of 550-230 cm-1 for identification of inorganic pigments. Spectrochim Acta Part A Mol Biomol Spectrosc. 2010;75(3):1061-72.

62. Liese HC. An infrared absorption analysis of magnetite. Am Mineral. 1967;52:1198-205.

63. Hayes PA, Vahur S, Leito I. ATR-FTIR spectroscopy and quantitative multivariate analysis of paints and coating materials. Spectrochim Acta Part A Mol Biomol Spectrosc. 2014;133:207-13. https://doi.org/10.1016/j. saa.2014.05.058.

64. Mazzeo R, Prati S, Quaranta M, Joseph E, Kendix E, Galeotti M. Attenuated total reflection micro FTIR characterisation of pigment-binder interaction in reconstructed paint films. Anal Bioanal Chem. 2008;392(1-2):65-76.

65. Coccato A, Moens L, Vandenabeele P. On the stability of mediaeval inorganic pigments: a literature review of the effect of climate, material selection, biological activity, analysis and conservation treatments. Herit Sci. 2017;5(1):12. https://doi.org/10.1186/s40494-017-0125-6.

66. Gelzo M, Grimaldi M, Vergara A, Severino V, Chambery A, Dello Russo A, et al. Comparison of binder compositions in Pompeian wall painting styles from Insula Occidentalis. Coke Chem. 2014;8(1):1-10.

67. Vahur S, Teearu A, Peets P, Joosu L, Leito I. ATR-FT-IR spectral collection of conservation materials in the extended region of $4000-80 \mathrm{~cm}-1$. Anal Bioanal Chem [Internet]. 2016:408(13):3373-9. Available from: https://doi. org/10.1007/s00216-016-9411-5.

68. Aliatis I, Bersani D, Campani E, Casoli A, Lottici PP, Mantovan S, et al. Pigments used in Roman wall paintings in the Vesuvian area. J Raman Spectrosc. 2010;41(11):1537-42.

69. Sciuti S, Fronterotta G, Vendittelli M, Longoni A, Fiorini C. A non-destructive analytical study of a recently discovered roman wall painting. Stud Conserv. 2001;46(2):132-40. http://www.jstor.org/stable/1506843.

70. Weber J, Prochaska W, Zimmermann N. Microscopic techniques to study Roman renders and mural paintings from various sites. Mater Charact. 2009.

71. Uvarov V, Popov I, Rozenberg S. X-ray diffraction and SEM Investigation of Wall Paintings Found in the Roman Temple Complex at Horvat Omrit. Israel Archaeometry. 2015;57(5):773-87.

72. Apostolaki C, Perdikatsis V, Repuskou E, Brecoulaki H, Lepinski S. Analysis of Roman wall paintings from ancient Corinth/Greece. Adv Miner Resour Manag Environ Geotechnol Hania. 2006;2006:729-34.

73. Perez-Rodriguez JL, de Haro MDCJ, Siguenza B, Martinez-Blanes JM. Green pigments of Roman mural paintings from Seville Alcazar. Appl Clay Sci. 2015;116-117:211-9.

74. Benvenuti M, Dini A, D'Orazio M, Chiarantini L, Corretti A, Costagliola P. The tungsten and tin signature of iron ores from Elba island (Italy): a tool for provenance studies of iron production in the mediterranean region. Archaeometry. 2013;55(3):479-506.

75. Marcaida I, Maguregui M, Fdez-Ortiz de Vallejuelo S, Morillas H, PrietoTaboada N, Veneranda M, et al. In situ X-ray fluorescence-based method to differentiate among red ochre pigments and yellow ochre pigments thermally transformed to red pigments of wall paintings from Pompeii. Anal Bioanal Chem. 2017:409(15):3853-60.

76. Sánchez-Moral S, Luque L, Cañaveras JC, Soler V, Garcia-Guinea J, Aparicio A. Lime-pozzolana mortars in Roman catacombs: composition, structures and restoration. Cem Concr Res. 2005;35(8):1555-65.

77. Sanchez-Moral S, Luque L, Cañaveras JC, Jurado V, Hermosin B, SaizJimenez C. Bioinduced barium precipitation in St. Callixtus and Domitilla Catacombs Ann Microbiol. 2004;54(1):1-12.

78. Kopczynski N, de Viguerie L, Neri E, Nasr N, Walter P, Bejaoui F, et al. Polychromy in Africa Proconsularis: investigating Roman statues using X-ray fluorescence spectroscopy. Antiquity. 2017;91(355):139-54.

79. Walton MS, Trentelman K. Romano-Egyptian red lead pigment: a subsidiary commodity of spanish silver mining and refinement. Archaeometry. 2009;51(5):845-60. 
80. Fermo P, Delnevo E, Vos M De, Andreoli M, Gianelle V, De Vos M, et al. Caratterizzazione di pigmenti antichi provenienti dalle Domus sotto la Basilica dei SS. Giovanni e Paolo, Celio (Roma). In: Bacci M, editor. COLORE E ARTE: STORIA E TECNOLOGIA DEL COLORE NEI SECOLI. Bologna: Patron Editore; 2008. pp 320-4. https://iris.unitn.it/handle/11572/91602\#.X|4t6 6hKhPY.

81. Zucconi L, Gagliardi M, Isola D, Onofri S, Andaloro MC, Pelosi C, et al. Biodeterioration agents dwelling in or on the wall paintings of the Holy Saviour's cave (Vallerano, Italy). Int Biodeterior Biodegrad. 2012;70:40-6.

\section{Publisher's Note}

Springer Nature remains neutral with regard to jurisdictional claims in published maps and institutional affiliations.

\section{Submit your manuscript to a SpringerOpen ${ }^{\odot}$ journal and benefit from:}

- Convenient online submission

- Rigorous peer review

- Open access: articles freely available online

- High visibility within the field

- Retaining the copyright to your article

Submit your next manuscript at $\boldsymbol{\nabla}$ springeropen.com 